IZA DP No. 4784

Technical Change and Total Factor Productivity Growth: The Case of Chinese Provinces

Almas Heshmati

Subal C. Kumbhakar

February 2010

Forschungsinstitut zur Zukunft der Arbeit Institute for the Study of Labor 


\title{
Technical Change and Total Factor Productivity Growth: The Case of Chinese Provinces
}

\author{
Almas Heshmati \\ Seoul National University \\ and IZA \\ Subal C. Kumbhakar \\ Binghamton University

\section{Discussion Paper No. 4784 \\ February 2010} \\ IZA \\ P.O. Box 7240 \\ 53072 Bonn \\ Germany \\ Phone: +49-228-3894-0 \\ Fax: +49-228-3894-180 \\ E-mail: iza@iza.org
}

Any opinions expressed here are those of the author(s) and not those of IZA. Research published in this series may include views on policy, but the institute itself takes no institutional policy positions.

The Institute for the Study of Labor (IZA) in Bonn is a local and virtual international research center and a place of communication between science, politics and business. IZA is an independent nonprofit organization supported by Deutsche Post Foundation. The center is associated with the University of Bonn and offers a stimulating research environment through its international network, workshops and conferences, data service, project support, research visits and doctoral program. IZA engages in (i) original and internationally competitive research in all fields of labor economics, (ii) development of policy concepts, and (iii) dissemination of research results and concepts to the interested public.

IZA Discussion Papers often represent preliminary work and are circulated to encourage discussion. Citation of such a paper should account for its provisional character. A revised version may be available directly from the author. 


\section{ABSTRACT \\ Technical Change and Total Factor Productivity Growth: The Case of Chinese Provinces}

In the literature technical change is mostly assumed to be exogenous and specified as a function of time. However, some exogenous external factors other than time can also affect technical change. In this paper we model technical change via time trend (purely external non-economic) as well as other exogenous (external economic) factors (technology shifters). We define technology index based on the external economic factors which are indicators of 'technology'. Thus our definition of production function is amended to accommodate several technology shifters which are not separable from the traditional inputs. That is, these technology shifters allow for non-neutral shift in the production function. In doing so we are able to decompose technical change (a component of TFP change) into two parts. One part is driven by time (manna from heaven) and the other part is related to producer specific external economic factors. These exogenous technology shifters are aggregated (via hedonic aggregator functions) into several groups (technology indices) for parsimonious parametric specification. The empirical model uses panel data on Chinese provinces. We identify a number of key technology shifters and their effect on technical change and TFP growth of provinces.

JEL Classification: $\quad$ C33, C43, D24, O18, O47

Keywords: technical change, total factor productivity growth, technology indicator, technology shifter, Chinese provinces

Corresponding author:

Almas Heshmati

TEMEP \#37-306, College of Engineering

Seoul National University

San 56-1, Shilim-dong, Kwanak-Gu

Seoul, 151-742

South Korea

E-mail: heshmati@snu.ac.kr 


\section{INTRODUCTION}

Measurement of technical change (TC) and total factor productivity (TFP) growth has been the subject of investigations in many empirical studies on industrial productivity (for example, Jorgenson, 1995). These studies have followed several well-known directions. The various approaches used in the literature have been classified by Diewert (1981) into: parametric estimation of production and cost functions, non-parametric indices, exact index numbers, and non-parametric methods using linear programming. In the nonparametric approach, the Divisia index has been widely used as a convenient measure of TFP growth over time and space as well. An important feature of the Divisia measure of TFP growth is that it coincides with the technical change when the underlying technology is homogeneous of degree one. However, empirical studies on production functions based on panel data do not support constant returns to scale technology (see Atkinson and Cornwell, 1994a, 1994b; and Biorn and Klette, 1996). If this property does not hold TFP growth becomes a mixture of technical change and scale effects. In the case of nonconstant returns to scale technology, decomposition of TFP growth into its sources requires knowledge of scale effects, which require econometric estimation of parametric functions.

In the parametric specification of technology using production/cost/profit functions, a widely used practice has been to use quadratic function of time trend to represent technical change. Notwithstanding its widespread use, the use of time trend is a mere reflection of our ignorance. Baltagi and Griffin (1988) has shown that if a panel data set is available, we could estimate a time specific parameter referring to the state of technology (general index of technical change) instead of using time trend. The method applied to analysis of manufacturing industry performance has shown evidence of erratic patterns of technical change which limits its usefulness in capturing technical change (see Kumbhakar and Heshmati, 1996; and Kumbhakar, Nakamura and Heshmati, 2000). Different generalizations of time trend (TT) and general index (GI) models of technical change have been developed and their performance and sensitivity using different datasets evaluated (see Heshmati and Nafar, 1998; Kumbhakar, Heshmati and Hjalmarsson, 1999; Kumbhakar, 2000; and Oh, Heshmati and Loof, 2009).

Econometric approach where technical change has been represented by a simple time trend or time dummies still dominates the empirical research. The popularity of time trend model comes from the fact that it is good in revealing long-run trends in technical change while general index model is good in capturing year to year variations (which may be caused by economy wide, sector-specific or firm-specific product or process innovations and demand or supply shocks). Despite of this popularity, the time trend model has been criticized because it reflects only our ignorance about the process. The general index overcomes the trend limitation by not imposing any systematic structure on the behavior of technical change, but it is by no means any better in explaining technical change. In both approaches TC is modeled entirely in terms of time and they fail to account for determinants of technological change and productivity growth. If two firms have the same inputs then their TC will also be the same. In the general index model determinants of TC are not directly used in the model. These are used in a second stage regression, therefore fails to take into account their direct or interactive effects with the traditional inputs. 
In an attempt to remedy the above limitations, this paper is concerned with specification and estimation of technical change by utilizing observable determinants of technical change (TC). Here we argue that TC, given the inputs (X), is likely to be governed by some exogenous variables $(\mathrm{Z})$ which are producer-specific. Time trend (time dummies) might be a component in it to reveal the long-run trends (year to year variations) in technical change. We generalize the concept and define an aggregator function, $\mathrm{T}(\mathrm{Z}, \mathrm{t})$, and argue that this function becomes an argument in the production function. That is, with this technology index we can write the production function as $\mathrm{Y}=\mathrm{f}(\mathrm{X}, \mathrm{T}(\mathrm{Z}, \mathrm{t}))$ and calculate technical change treating $\mathrm{T}(\mathrm{Z}, \mathrm{t})$ as a covariate in the production function. From this formulation we can separate out the impact of $\mathrm{Z}$ variables and time in TC. That is, TC defined in this way can be broken down to time-specific and Z-specific components. If $\mathrm{Z}$ variables are producer-specific, TC will be different for different producers even if the inputs (X) are exactly the same. If there is no $\mathrm{Z}$ variable in the model then our TC will be identical to TC in the TT model. If we put time dummies in the T(.) function and there are no Z variables, then our TC will be the same as Baltagi and Griffin's GI model of TC. Our present model allows estimation of TFP growth and its decomposition into technical change and scale components, as well as marginal effects of the technology indices and their underlying components.

In modeling TC our focus is on various key external economic factors contributing to shift in production. These factors (Z), in our empirical model, are related to human capital, information and communication technology, foreign direct investment and reform programs. These shift variables in addition to yielding producer-specific technical change and factor bias (both in inputs and scale) in the overall TC measures, help us to estimate the contribution of the $\mathrm{Z}$ and $\mathrm{t}$ variables separately into TC and TFP growth. By using a flexible functional form and conducting sensitivity analysis we examine robustness of the estimates of TFP growth and its components.

Instead of using one aggregator function to define a single technology index $\mathrm{T}(\mathrm{Z}, \mathrm{t})$, one can think of several aggregator functions $T_{j}\left(Z_{j}\right)$ which are indices of technology. These indices which are functions of elements of $\mathrm{Z}$ are used to define technology indices. Time variable can be one index of its own, $\mathrm{T}(\mathrm{t})$. With these technology indices, the production function can be written as $\mathrm{Y}=\mathrm{f}\left(\mathrm{X}, \mathrm{T}_{\mathrm{j}}\left(\mathrm{Z}_{\mathrm{j}}\right), \mathrm{T}(\mathrm{t})\right)$. The advantage of the multiple index technology is that it is more flexible in separating the effects of different technology shifters and important instrument in design and implementation of industrial technology policy. Note that the present formulation is more general and the previous formulation with a single technology index becomes a special case.

For the empirical analysis we use input and output data and production and technology characteristics for Chinese provinces observed for the period 1993 to 2003. The analysis is expected to improve our understanding of the causes and patterns of growth rate of provincial technical change and TFP growth in China. It enhances our knowledge on the causes and patterns of recent years of heterogeneous regional development in China. Information on differences in regional productivity growth is important for the government to formulate better policies of allocation and redistribution of productive resources to reduce the growing regional inequality in the country. 
The present paper contributes to the literature in a number of ways. First, it tries to explain technical change based on actual observable exogenous external indicators or technology shifters that are not separable from the traditional inputs. These exogenous technology shifters are further aggregated into several technology groups. Second, we use panel data methodology and flexible functional form in which we control for province-specific effects that are not necessarily associated with technological change. Third, the growth rate is decomposed into time driven and technology shifter driven yet producer-specific components. Fourth, the model is applied to estimation of productivity growth in 30 Chinese provinces during the country's rapidly growth period of 1993 to 2003. Fifth, unlike other previous growth studies of China, which mainly apply the growth accounting approach (e.g. Chow, 1993; Borensztein and Ostry, 1996; World Bank, 1996; Hu and Khan, 1997; Maddison, 1998; Woo, 1998; Ezaki and Sun, 1999; Demurger, 2000; Wang and Yao, 2003; and Arayama and Miyoshi, 2004), this paper applies the panel data approach for estimation of the production function. The growth accounting approach which focuses on limited number of inputs, imposes strong assumption of constant returns to scale and uses fixed income shares over long period of time, tends to overestimate productivity growth. Sixth, we identify a number of key policy relevant technology shifters and their effects on TFP growth of provinces.

The rest of the paper is organized as follows. Section 2 reviews the earlier literature on Chinese provincial growth studies. Description of the Chinese provinces and the data are given in Section 3. The factors explaining TC and technological biases are described in Section 4. Specification tests and estimation issues are discussed in Section 5. Empirical results are discussed in Section 6. The concluding section summarizes the results of this study.

\section{CHINESE PROVINCIAL GROWTH STUDIES}

China's achievement of high economic growth since the adoption of the open-door policy in 1978 has been a source of admiration and a model for development policy. The average annual growth rate of real GDP over the past twenty-five years was 9.37\% (Holz, 2005). This remarkable economic growth has led to a heated debate on whether the economic growth is a result of productivity growth or factor accumulation. Several studies have found that the country's high growth rate was brought about mainly by capital accumulation (e.g. Chow, 1993; Yusuf, 1994; Borensztein and Ostry, 1996; Hu and Khan, 1997; Sachs and Woo, 1997; Woo, 1998; Ezaki and Sun, 1999; Wu, 2004; and Arayama and Miyoshi, 2004). According to Krugman (1994), the massive accumulation of inputs will soon limit China's growth potential if there is little improvement in productivity. Indeed, the state's and province's stress of promoting productivity growth in the 90s led to dramatic increases in volume of research and development expenditure at different levels over the past decade. The Chinese productivity growth rate has almost sustained even under the 1997 Asian and current global financial crisis.

Other than the above mentioned analysis of sources of growth of TFP, a number of productivity studies on China's economy examined productivity differences by types of 
ownership (e.g. Jefferson, 1990; Dollar, 1992; Jefferson and Xu, 1994; Chen et al., 1998; Xu and Wang, 1999; Hu, 2001; and Zheng et al., 2003). A number of other categories of productivity research include the examination of sectoral productivity growth differences (e.g. Lin, 1992; Jefferson, Rawski and Zheng, 1992, 1996; Wu, 1995, 2000; Xu, 1999; and Zheng and Zheng, 2001) and the investigation of productivity difference among regions in China (e.g. Lee, 2000; Song et al., 2000; Cai et al., 2001; Demurger, 2001; Bao et al., 2002; and Demurger et al., 2002). A few of the datasets used in the above studies are at the firm level, while majority of them are at the aggregate national, sectoral, regional or provincial levels. Recently Maddison and Wu (2008) suggested that the official Chinese National Bureau of Statistics exaggerated GDP growth and adjustment to conform to international norms. They present and discuss the necessary adjustments by contributions along new volume indices for the industrial sector and for services. These authors use a measure of purchasing power parity instead of the exchange rate.

The methodology used in the analysis of productivity in China is diverse. These include both non-parametric and parametric approaches. The non-parametric can be divided into growth accounting and Malmquist productivity indices. A handful of studies have applied the growth accounting approach (e.g. Chow, 1993; Borensztein and Ostry, 1996; World Bank, 1996; Hu and Khan, 1997; Maddison, 1998; Woo, 1998; Ezaki and Sun, 1999; Demureger, 2000; Wang and Yao, 2003; and, Arayama and Miyoshi, 2004). The growth accounting approach involves the subtracting of the growth of factor accumulation at a constant rate from the output growth to obtain the TFP measure. In this case with constant returns to scale, TFP is equivalent to technical change. Some of the studies above used Cobb-Douglas average production function (such as Chow, 1993; Ezaki and Sun, 1999; and Wang and Yao, 2003), while others (like Hu and Khan, 1997; and Arayama and Miyoshi, 2004) applied the translog production function. These studies focus on the estimation of factor input shares to be used in the computation of the aggregate productivity growth over time. All of these studies have found positive TFP growth in post-reform China.

Chen (2001) and Zheng and Hu (2004) applied the Malmquist indexes of TFP growth. The Malmquist index measures the TFP change between two data points by calculating the ratio of the distances of each data point relative to a common technology. The TFP growth can be decomposed into two components, namely efficiency change and technological change. Chen (2001) found positive average TFP growth and technology improvement was found to be a larger component for TFP growth. Zheng and Hu (2004) found considerable average productivity growth, which was accomplished through technical progress instead of efficiency improvement. The parametric approach involves both average and frontier functions. There are few studies which used the frontier production approach to measure TFP growth in China. Wu (1999) applied the stochastic frontier approach on Chinese provinces to examine the productivity growth in China's reforming economy. Wu found positive TFP growth during the post-reform period.

A symposium published by European Journal of Comparative Economics, edited by Dougherty and Valli (2009), offers in-depth discussion of growth pattern of China and India and their influence in the world market. The essays examine economic and human 
development indicators (Basu, 2009); complexities of economic transformation (Valli and Saccone, 2009); trade integration and changing specialization (Benisdoun, Lemoine and Unal, 2009); and their macroeconomic policies and exchange rate regimes (Patnaik and Shah, 2009).

Basu's examination aimed at finding evidence of the welfare and equity shifts in the two economies' growth performance. The Chinese economic development index grew three times faster over the reform period while India's human development did grow more rapidly and less regionally polarized. Kash, Auger and Li (2004) suggest that historical and cultural differences appear to explain some of the differences in the development patterns of firms located in the two countries. In a related study Hsieh and Klenow (2007) suggest that resource misallocation can lower aggregate total factor productivity in manufacturing. A hypothetical reallocation of labor and capital to equalize USA marginal products would lead to gains in manufacturing TFP by $25-40 \%$ in China and $50-60 \%$ in India.

Valli and Saccone (2009) analyzed the feedback loops from increasing scale, profits, investment, and facilitating various types of productivity-enhancing shifts. The shifts seem to continue as the economies become increasingly integrated with the global economy. Benisdoun, Lemoine and Unal (2009) and Lemoine and Unal (2004) indicate that China has become a major hub for segmented global production process. Chen and Feng (2000) analyze tariff structure, openness and trade policy in China and find employment, profitability, concentration, WTO and other factors among the main determinants of endogenous trade policy. China's industrial policy regime has played an important role in the country's economic development and participation in the world economy.

In a similar study Lu (2000) examined the effect of industrial policy regime on crossindustry resource allocation. The results showed effectiveness of industrial policy in offering incentives and controlling openness to be in line with the planned priority. Lu also examined the growth of technological capability and $\mathrm{Mu}$ and Lee (2005) technological learning and catching-up in telecommunication industry in China. They found that the important factors in the catch-up are the conditions for catch-up, strategy of "trading market for technology", knowledge diffusion, and industrial promotion by the government. Patnaik and Shah (2009) suggested that the exchange rate policies of China may have contributed to partially shelter it from the world financial crisis. The fall of exports will induce the government to focus more on the development of its internal market, building up development infrastructure and investment in welfare policy programs.

The existing literature on technology sources at the Chinas provincial level is poor and it does not provide sufficient understanding of the sources of technology changes. Few studies attempt to investigate technology in general or specific to sectors of the economy. Yang (2009) looked into whether China's high economic growth is due to productivity growth after the mid-1990s when China devoted more efforts to R\&D and innovative activities. Yang evaluated regional productivity growth in China and analyzed the impacts of certain sources on the technology ladder. The results showed differences in productivity growth between the coastal and non-coastal regions and technological progress among the former relies heavily on foreign knowledge. In-house R\&D, FDI and technology import positively affected productivity. 
Liu (2002) also found that FDI has a large spillover effect on the level and growth in manufacturing and in particular on domestic firms in China. Chen and Song (2008) utilized county level data to examine technical efficiency and technology gap in China's agriculture. They classified the counties into four regions. The result suggests that technology and knowledge diffusion within region might help to improve production efficiency. In another study Meng and Li (2002) showed evidence of ICT industry development and diffusion but also huge gap between China and developed nations in this regards as well as digital divide among different economic regions. Gao (2004) examined regional industrial development in China with emphasis on factors representing sources of regional growth. Gao found that local competition, small size of state sector, better transport system, and exports and FDI positively effect on regional industrial growth.

In this study, in addition to the methodological contribution concerning the modeling exogenous determinants of technological change, we contribute to the existing research which focuses on the investigation of sources of economic growth in China. In particular, in addition to traditional inputs, we incorporate several indicators of technology. One such indicator is ICT investment as an infrastructure for economic development in China in the age of New Economy. Other indicators are human capital and its role in acquisition and absorption of new technology, skills and management. Although China has a rapidly growing ICT sector over the past decade, possibly because of data limitations, there is a lack of empirical research that examines contributions of ICT investment, FDI inflows, human capital and importance of reform to the Chinese economic growth. Meng and Li (2002) is one of few studies which provided some evidence on China's ICT industrial development and diffusion in recent years. Heshmati and Yang (2005) also investigated the relationship between TFP growth and ICT investment but at the aggregate national level, and unlike in the case of developing countries, they provided estimation of positive returns to ICT investment in China. Our data allow us to consider productivity growth measures at the national, regional and provincial levels. Thus, we are able to have a more thorough understanding of the provincial and regional diversity of growth patterns in China.

We apply the panel data econometric approach for estimation of the production function, instead of using the growth accounting, Malmquist or frontier production function approaches. The growth accounting approach which focuses on limited number of inputs and uses constant returns to scale assumption and fixed income share over long period of time tends to produce biased and overestimated measure of growth. The Malmquist approach overcomes some of these limitations and allows decomposition of productivity growth but account only for few key production inputs. This study by applying the panel data models for parametric estimation of the technical change, allow to controls for unobservable time invariant provincial effects. In addition technological change is modeled via exogenous factors and the production function specification is enriched by the introduction of non-traditional production factor inputs. These include factors such as ICT investment, inflow of FDI, human capital and economic reform measures which by experts are considered crucial for growth and development in general and to the Chinese economy in particular which has benefited from these factors in its emergence and catch up. 


\section{THE PROVINCE LEVEL DATA}

In this paper, we use a combination of officially published and non-published provincial data of China, which provide information on the contributing factors to the development of the technical change and TFP growth in China during the recent years of rapid economic growth.

The data for estimation of the translog production function and technological index comprises the following output, input and technology indicator variables for 30 provinces during the period 1993 to 2003. Output is measured as aggregate gross domestic product (GDP) (in 100 million Yuan). The input variables include labor measured by the number of persons employed at year-end (in thousands) and capital stock (CAP) (in 100 million Yuan). The technology index is modeled using information and communication technology (ICT) investment (in 100 million Yuan), foreign direct investment (FDI) inflow (in 10,000 US\$), percentage of highly educated labor (PCNT) (the ratio of number of graduates of regular institutions of higher education to population), and reform (REFORM) (the ratio of state-owned enterprises industrial value to total gross industrial value). These capture financial, technological, human capital and reform components of technology development, transfer and absorption by provinces in different years.

In specifying the technology index we tried a number of other indicators, but the model specification was highly nonlinear and difficult to further generalize. Other variables considered are road infrastructure (ROAD) (total length of highways in km), government consumption (GOV) (in 100 million Yuan), total domestic investment (INV) (in 100 million Yuan), household telephone subscribers (TEL) (in number of subscribers), and openness a proxy for globalization (OPEN) (the ratio of import plus export to GDP). In addition we use dummy variables to control for unobserved time-invariant province specific effects such as skills, planning and management differences, and location advantages/disadvantages of the provinces. A simple time trend (TRN) is added to the specification of the production function to capture possible trend in the use of inputs and output produced. It captures the unobserved exogenous components of technical change and productivity growth as well as province-specific effects such as central or local government economic policy effects.

All the input variables which are originally expressed in nominal prices are deflated using GDP deflator which varies across provinces and time. The nominal and real GDP indexes are derived based on data from various Chinese Statistical Yearbooks and calculated the GDP deflators accordingly. There were smooth increasing trends of the calculated GDP deflators and no abnormalities were found. The physical capital stock data from 1993-2003 is taken from $\mathrm{Wu}$ (2004). The authors extended the series to include 2003 data using the back casting method. It is calculated based on the assumption that the rate of depreciation is $4.0 \%$. The series is expressed in 1952 constant prices.

The data is mainly taken from various issues of Chinese Statistical Yearbooks and the official Chinese government websites. The ICT investment data was supplied by the statistical department of Ministry of Information Industry (MII). The ICT investment

includes investments in the production of radios, televisions, fixed telephones, mobile 
telephones, personal computers and communication equipments. The share of ICT investment to total investment was around $1 \%$ during the early $80 \mathrm{~s}$, but it has increased to approximately 5\% in the late 90s and after 2000.

The total number of observations $(\mathrm{NxT})$ is $30 \times 11=330$. Table 1 shows the summary statistics of the deflated variables used in the paper, including average GDP, inputs, as well as other production and technology indicators.

Insert Table 1 Summary statistics about here

\section{MEASUREMENT AND DECOMPOSITION OF PRODUCTIVITY GROWTH}

We mentioned different approaches to measure productivity growth. Here we deal with the definition and measurement issues. In economics productivity is defined quite broadly. Here we focus on TFP as an appropriate measure of productivity. Production process can be a single or multi-output operation. In a single output case TFP growth (TFP) is defined as $T \dot{F P}=\dot{Y}-\sum_{j} S_{j} \dot{X}_{j}$, where $Y$ is output, $X_{j}$ is a vector of inputs $(j=1,2, \ldots ., \mathrm{J}), S_{j}$ is the share of input $X_{j}$ in the total cost, $S_{j}=w_{j} X_{j} / \sum_{j} w_{j} X_{j}, w_{j}$ being the price of input $X_{j}$, and a dot over a variable indicates its annual rate of change. If there are multiple outputs the TFP growth is expressed as $T \dot{F P}=\sum_{m} R_{m} \dot{Y}-\sum_{j} S_{j} \dot{X}_{j}$, where $R_{m}$ is the output value share, $R_{m}=P_{m} Y_{m} / \sum_{m} P_{m} Y_{m}$, and $P_{m}$ is the price of output $Y_{m}(m=1, \ldots . ., \mathrm{M})$. Using the above definitions, the $T \dot{F} P$ measure can be computed from the observed data without any estimation. The resulting measure is called the Divisia index of TFP growth. It gives us information about output growth that is not explained by the growth of the factor inputs used in production.

The Divisia index is non-parametric and as such it does not provide information on the factors affecting productivity growth. The main advantage of the parametric or econometric approach is that we can both estimate and decompose TFP growth. The econometric approach is based on primal (production) or dual (cost) or profit functions. The choice of the cost function has some advantages over the production as well as the profit function in productivity growth analysis. First, unlike a single equation, a cost function can handle multiple outputs quite easily and can be estimated econometrically. Second, a cost function can be estimated without imposing any restriction on the implied returns to scale. This is not possible in a profit function for which returns to scale has to be less than unity. Third, in a service industry outputs may be demand determined where the producer's object is to minimize cost for given output. Finally, in a cost function approach it is not necessary to assume that output markets are competitive. The cost function parameters can be consistently estimated even if output markets are non-competitive. ${ }^{1}$

In this study we employ a production function approach. The main advantages with

\footnotetext{
${ }^{1}$ Some of the earlier works can be found in the Cowing and Stevenson (1981) edited volume "Productivity Measurement in Regulated Industries". For some recent studies see, for example, Atkinson and Halvorsen 1984; Baltagi and Griffin 1988; Kumbhakar 1992; Bhattacharyya et al. 1997, among others.
} 
production function are that it does not require information on prices and it allows for nonconstant returns to scale. It has several desirable properties such as: positive marginal product of inputs, non-emptiness of output, symmetry, monotonicity and convexity. In addition, the production function is assumed to be continuous at any point and twicecontinuously differentiable. The translog production function with a time trend representing exogenous technical change can be written as:

$$
\begin{aligned}
\ln Y_{i t}=\beta_{0} & +\sum_{j=1}^{J} \beta_{j} \ln X_{j i t}+\beta_{t} T_{t}+1 / 2\left(\sum_{j=1}^{J} \sum_{k=1}^{K} \beta_{j k} \ln X_{j i t} \ln X_{k i t}+\beta_{t t} T_{t}^{2}\right) \\
& +\sum_{j=1}^{J} \beta_{j t} \ln X_{j i t} T_{t}+\varepsilon_{i t}
\end{aligned}
$$

where $\ln Y_{i t}$ is the logarithm of output measure of total GDP of province $i(i=1,2, \ldots, \mathrm{N})$ in period $t(t=1,2, \ldots, \mathrm{T})$ and $\ln X_{i t}$ is a vector of logarithm of $J(j=1, \ldots, \mathrm{J})$ inputs. The inputs include labor (LAB) and capital stock (CAP), $\mathrm{T}$ is a time trend and $\beta$ 's are unknown parameters to be estimated. The error term is decomposed into time-invariant provincespecific effects $\left(\mu_{i}\right)$ and a random error term $\left(v_{i t}\right), \varepsilon_{i t}=\mu_{i}+v_{i t}$, with mean 0 and constant variance, $\sigma_{v}^{2}$. The $\mu_{i}$ are assumed to be fixed parameters and are captured by $\mathrm{N}-1$ province dummies.

The specification of technical change in (1) is represented by a simple time trend. Econometrically the production function in (1) can be extended to incorporate various 'technology shifters' that are functions of exogenous factors, viz.:

$$
\begin{aligned}
\ln Y_{i t}=\beta_{0} & +\sum_{j=1}^{J} \beta_{j} \ln X_{j i t}+\beta_{t} T_{t}+\sum_{m=1}^{M} \beta_{m} T_{m}\left(Z_{i t}^{m}\right) \\
& +1 / 2\left(\sum_{j=1}^{J} \sum_{k=1}^{K} \beta_{j k} \ln X_{j i t} \ln X_{k i t}+\beta_{t t} T_{t}^{2}+\sum_{m=1}^{M} \sum_{l=1}^{L} \beta_{m l} T_{m}\left(Z_{i t}^{m}\right) T_{l}\left(Z_{i t}^{l}\right)\right) \\
& +\sum_{j=1}^{J} \beta_{j t} \ln X_{j i t} T_{t}+\sum_{j=1}^{J} \sum_{m=1}^{M} \beta_{j m} \ln X_{j i t} T_{m}\left(Z_{i t}^{m}\right)+\sum_{m=1}^{M} \beta_{t m} T T_{m}\left(Z_{i t}^{m}\right)+\varepsilon_{i t}
\end{aligned}
$$

where $T_{m}\left(Z_{i t}^{m}\right)$ are technology indices and $Z^{m}$ are external economic factors (labeled as technology shifters). That is, given the traditional inputs, outputs can change depending on the level of the variables that can shift the production function. These shift variables can be grouped into various components (technology indices) $T_{m}\left(Z_{i t}^{m}\right)$, where each component depends on a subset of mutually exclusive shift variables. Thus, we can specify $T_{m}\left(Z_{i t}^{m}\right)$ as:

$$
T_{m}\left(Z_{i t}^{m}\right)=\ln \left(\sum_{p=1}^{P_{m}} \gamma_{p}^{m} Z_{p i t}^{m}\right), \sum_{p=1}^{P_{m}} \gamma_{p}^{m}=1 \forall m
$$

where $P_{m}$ is the number of technology shifters in technology index $\mathrm{T}_{\mathrm{m}}($.$) . In this paper we$ use two technology indices, each based on two technology shifters. The first technology 
index $\left(T_{1}().\right)$ is constructed from human capital and development infrastructure and it is based on percentage of labor with university education (PCN) and reform program (REFORM). The second index $\left(T_{2}().\right)$ is constructed around financial market and is based on investment in information and communication technology (ICT) and inflow of foreign direct investment (FDI). ${ }^{2}$ In defining each of the indices we restrict sum of the weights to be unity (identifying restrictions) so that we can interpret the weights as 'importance' of each shifter on the technology component. There are other ways of imposing identifying constraints on the $\gamma_{p}^{m}$ parameters but none of them will have the easy and intuitive interpretation similar to the one we used.

The production model is estimated using fixed effect panel data approach with the specification of a translog functional form, by which the technology is represented in two ways by: (i) a time trend and (ii) a simple time trend and technology indices. We call the former the single Time Trend (TT) model whereas the latter is called the technology index (TI) model. The two models are nested and the former is a restricted version of the later.

Based on equations (2) and (3), the input elasticities (E) and the technical change (TC) can be calculated as follows for each of the two models:

$$
\begin{aligned}
& E_{j i t}^{T T}=\partial \ln Y_{i t} / \partial \ln X_{j i t}=\beta_{j}+\beta_{j j} \ln X_{j i t}+\beta_{j t} T_{t} ; \\
& E_{j i t}^{T I}=\partial \ln Y_{i t} / \partial \ln X_{j i t}=\left(\beta_{j}+\beta_{j j} \ln X_{j i t}+\beta_{j t} T_{t}\right)+\left(\sum_{j=1}^{J} \beta_{j m} Z_{m i t}\right) ; \\
& T C_{i t}^{T T}=\partial \ln Y_{i t} / \partial T_{t}=\beta_{t}+\beta_{t t} T_{t}+\sum_{j} \beta_{j t} \ln X_{j i t} ; \text { and } \\
& T C_{i t}^{T I}=\partial \ln Y_{i t} / \partial T_{t}=\left(\beta_{t}+\beta_{t t} T_{t}+\sum_{j=1}^{J} \beta_{j t} \ln X_{j i t}\right)+\left(\sum_{m=1}^{M} \beta_{t m} Z_{m i t}\right) .
\end{aligned}
$$

In similar way the elasticity for each technology index, here $T_{m}\left(Z_{i t}^{m}\right)$, is also calculated from

$$
E_{m i t}^{Z}=\partial \ln Y_{i t} / \partial \ln T_{m}\left(Z_{i t}^{m}\right)=\left(\beta_{m}+\beta_{m m} \ln Z_{m i t}+\sum_{j=1}^{J} \beta_{j m} \ln X_{j i t}+\beta_{t m} T_{t}+\beta_{Z l} T_{m}\left(Z_{i t}^{m}\right)\right)
$$

Note that purely exogenous technical change $\left(\mathrm{TC}^{\mathrm{TI}}\right)$ in $(5 \mathrm{~b})$ can further be decomposed into the pure $\left(\beta_{t}+\beta_{t t} T_{t}\right)$, non-neutral $\left(\sum_{j} \beta_{j t} \ln X_{j i t}\right)$, and technology index $\left(\sum_{m} \beta_{t m} T_{m}\left(Z_{i t}^{m}\right)\right)$ components. Pure technical change refers to neutral shift of the

\footnotetext{
${ }^{2}$ We also tried to account for other determinants such as general provincial investment expenditure (INV), infrastructure like roads (ROAD) and telephone lines (TEL), provincial government expenditure (GOV), and provincial openness (OPEN), but these were exclude because the model become highly non-linear and not converging.
} 
production function due to time alone, non-neutral technical change means input biased technical change, and technology index components is a results of effect of known exogenous technology shifters. Technical change is biased if the marginal rate of substitution between any two inputs measured along a ray through the origin is affected by technical change. It implies that technical change will tend to influence the relative contribution of each input to the production process.

Returns to scale (RTS) is obtained by summing all of the input elasticities calculated in equation:

$$
R T S_{i t}^{T T}=\sum_{j=1}^{J} E_{j i t}^{T T} \text { and } R T S_{i t}^{T I}=\sum_{j=1}^{J} E_{j i t}^{T I}
$$

where $E_{j i t}$ is the elasticity of output for province $i$ with respect to input $j$ at period $t$. It measures the percentage change of output in response to a $1 \%$ increase in all inputs simultaneously. Technology is said to be exhibiting increasing, constant or decreasing returns to scale, respectively, if RTS greater than, equal to or less than 1. All input elasticities, returns to scale and technical change are computed at every data point. By using equations (4) to (8), the parametric TFP growth based on the translog production function for both TT and TI models can be obtained as follow:

$$
\begin{aligned}
& T \dot{F} P_{i t}^{T T}=T C_{i t}^{T T}+\left(R T S_{i t}^{T T}-1\right) \sum_{j=1}^{J} E_{j i t}^{T T} \dot{X}_{j i t}=T C_{i t}^{T T}+S C A L E_{i t}^{T T} \text { and } \\
& T \dot{F} P_{i t}^{T I}=T C_{i t}^{T I}+\left(R T S_{i t}^{T I}-1\right) \sum_{j=1}^{J} E_{j i t}^{T I} \dot{X}_{j i t}+\sum_{m=1}^{M} E_{m i t}^{Z} \dot{T}_{m}\left(Z_{i t}^{m}\right)=T C_{i t}^{T I}+S C A L E_{i t}^{T I}+T Z_{i t}
\end{aligned}
$$

where $\mathrm{TZ}$ and $\mathrm{TC}^{\mathrm{TI}}$ together measure the overall technical change. The $\mathrm{TC}^{\mathrm{TI}}$ part is due to time alone (purely external non-economic factor) whereas the $\mathrm{TZ}$ part is due to other external economic factors. In our application TZ is a weighted average of the two technology index components, where the weights are the marginal effects of the index components. The overall TZ index is the sum of the product of the technology elasticity and growth rate of technology index, viz.,

$$
T Z_{i t}=\sum_{m=1}^{M}\left(\partial \ln Y_{i t} / \partial \ln T_{m}\left(Z_{i t}^{m}\right)\right)\left(\dot{T}_{m}\left(Z_{i t}^{m}\right)\right)
$$

Under constant returns to scale (CRS) and competitive output markets, TFP growth and technical change are identical (Solow 1957). In such a case it is not necessary to estimate anything econometrically, but computing Divisia index directly from the data. However, if the objective of producers is to minimize cost (given outputs) or maximize output (for given inputs), and the constant returns to scale and perfectly competitive output (input) market assumptions are relaxed, then it is possible to establish a relationship between the Divisia index and the TFP growth components (Denny et al. 1981). The TFP growth in (8a) and (8b) can be obtained from a parametric cost function or production function. The first component of TFP growth is TC and the second component is the Scale component, which is zero if RTS is unity. The last component is zero if either the marginal effect of 
every technology shifter is zero (i.e., they are not shifting the technology) or these shift variables are time-invariant. Note that in defining TFP change we are not taking into account the cost of these technology shift variables (assumed to be costless to change them).

It should be noted that, even with a CRS technology, other factors that can explain productivity growth may exist. If these factors are observed, we can separate the contribution of factors that are under the control of the producers (external economic factors) and those that are exogenous to the firm (purely external non-economic factors) by estimating the underlying production technology econometrically. The external factors which define the environment where the producers operate, could affect profitability, survival and productivity growth of firms. These factors are usually taken into account in the endogenous growth literature. Morrison (1986) and Morrison and Siegel (1999) include these factors in the productivity growth analysis. They point out that such external factors affect the cost-output relationship of the firm and can be explicitly included into the model as non-neutral shift variables. See also Winston (1993) and Vickers (1995). Here we use them as technology shifter and in the context of technological change.

\section{SPECIFICATION TESTS AND ESTIMATION}

As mentioned in the data section, we specify and estimate a translog production function for Chinese 30 provinces observed for the period 1993-2993. Output is measured as aggregate gross domestic product (GDP). The vector of inputs includes labor measured as the number of employees (LAB) and capital stock (CAP). The technology index is modeled using information and communication technology (ICT) investment, foreign direct investment (FDI) inflow, percentage of highly educated labor (PCNT), and a reform (REFORM) variable. These capture financial, technological, human capital and reform components of production technology by provinces. Several other production technology indicators (e.g. roads, government consumption, total investment, phone lines and openness) were also tried but removed from the specification due high degree of nonlinearity and convergence problems. A simple time trend (TRN) is also added to the specification to capture possible trend in the use of inputs and output. It captures the unobserved exogenous components of technical change as well as central or local economic policy effects facing all provinces equally. In addition we use dummy variables to control for unobserved effects such as skills, planning and management differences, and location advantages/disadvantages at the provinces.

We investigate the issues of multicollinearity and confounded effects (see Table 2). The explanatory variables labor (0.646) and capital (0.714) are positively and highly correlated with GDP. There is also a positive association between GDP and trend (0.398). The labor and capital are weakly correlated (0.232). Labor is not correlated with time trend, but capital is (0.294). The correlation coefficient among the variables shows that there is no

serious multicollinearity problem. FDI, ICT and REFORM variables are correlated with each other (0.326-0.672), but PCNT is not correlated (0.115-0.300) with any of the other three technology indicator variables. 


\section{Insert Table 2 Correlation matrix about here}

Several model specification tests are possible. First functional form can be tested by testing a flexible translog form versus a simple Cobb-Douglas form. Second, one can test significance of the two technology components individually or jointly. Third, a test of single or multiple technology index component. The first test, based on F-test, showed that the translog form is accepted. The second test also shows that technology component index should be included in the specification. We could not perform the third test because the model with a single technology index with four shift (external economic) variables did not converge. The time trend model (1) is estimated using PROC REG procedure and the technology index model (2) and (3) are estimated using non-linear procedure PROC MODEL in SAS 9.2. Using the parameter estimates various measures (4) through (9) such as predicted indices, marginal effects of indices and individual index indicators, rate of technical change, input elasticities, returns to scale, TFP and its decomposition into technical change, scale and technology index components, and their respective share are computed. Each of these components is discussed in more details in the next section.

\section{EMPIRICAL RESULTS}

\subsection{Parameter estimates}

The estimation results for both of the time trend (1) and technology index (2) and (3) models are reported in Table 3. In the time trend model all slope parameters with the exception of capital and its interaction with trend and labor squared are statistically significant. A total of 22 of the 29 province dummies are statistically different from the Ancui province which serve as reference. The highest intercepts are associated with Cenan and Gansu, while the lowest to Shanghai and Tibet. The results suggest significant heterogeneity among the provinces in China. The fit of the model is very good.

Insert Table 3 Parameter estimates about here

In the case of technology index model, 4 parameters are not significant at the 10 percent level of significance. These are: capital, index2, labor squared and index1 interacted with trend. Only 16 of the 29 province intercepts are significant at the less than 10 level of significance. The degree of heterogeneity is somewhat lower in this model compared with the time trend model. In terms of ranking the provinces by the level of intercept same inference as in case of time trend model can be made. The parameters of the two technology indices are of expected sign and all their interactions with two exceptions are statistically significant.

\subsection{Elasticities and returns to scale}

The input elasticities are estimated from the derivatives of the production functions with respect to labor and capital inputs (4a and $4 \mathrm{~b}$ ). In the case of simple time trend model, the first order capital coefficient and the interaction with labor are negative causing the overall labor elasticity to be negative. The negative interactive term suggest that the two inputs are 
substitutes. The sample mean elasticities of labor and capital are 0.545 and -0.230 , respectively. The returns to scale computed from equation (7) shows decreasing returns to scale ( 0.315).

\section{Insert Table 4 Correlation matrix about here}

The first order and second order capital coefficients in the technology index model are positive but the interaction with labor negative. Unlike in the time trend model where the regularity condition in case of capital was violated, the overall elasticities are positive. The two inputs interactions with the two technology indices are opposite. The two input elasticities are negatively correlated (-0.279) with each other. The input elasticities patterns again suggest that the two inputs are strongly substitutes. The sample mean elasticities of labor and capital are 0.267 and 0.289 , respectively. The returns to scale computed from equation (7) is 0.553 suggesting decreasing returns to scale and is agreement with the time trend model. The input elasticities and returns to scale across provinces, regions and over time are reported in Table 5.

Insert Table 5 Input elasticities and RTS about here

In both models the inputs elasticities and returns to scale measures, computed at each point, show large dispersions and in some cases show increasing returns to scale as well. In examining the differences across provinces, we observe that the mean labor elasticity is negative for Beijing, Jiangsu, Shandong, Shanghai and Lianing. It is highest for Tibet and Qincai. The capital elasticity is negative for Guangxi, Guizcou and Sichccon and highest for Beijing and Shanghai. The return to scale is increasing only in the case of Ningxi, Scaanxi and Tibet. In several provinces RTS is extremely low, below 0.20 . The mean input elasticities and returns to scale are almost constant over time. However, they differ by regional location. The highest labor elasticity is attributed to West, the highest capital elasticity to East, while the highest combined effect in form of returns to scale to West.

\subsection{Technology index and technical change}

Technical change in the time trend production function model is computed using (5a). The first and second order coefficients are significant suggesting increasing growth but at a decreasing rate. The interactions with labor and capital suggest labor-using technical change in Chinese provinces. The non-neutral component provides information about possible input using/saving biased technical change. The sample average of technical change in the time trend model is $13.7 \%$ and ranges from $4.2 \%$ to $22.3 \%$. It is the main contributor to TFP growth. ${ }^{3}$

In the technology index model, all of the time trend coefficients and their interactions with the exception of trend and technology index 1 are statistically significant. The coefficients of technology index indicators/shifters are also statistically significant, but not the aggregate of the two indices by themselves. However, their squares and interactions with one exception are significantly different from zero. Technical change in the technology

\footnotetext{
${ }^{3}$ Not reported here to conserve space.
} 
index model is computed using the formula (5b). Table 6 reports the correlation matrix of TC and TFP (0.172) components.

Insert Table 6 on Correlation matrix of TC and TFP about here

Table 7 shows that purely exogenous (driven by time) technical change is $3.5 \%$ and it ranges from $-9.0 \%$ to $15.4 \%$. It is positively related with TFP growth, but negatively with the scale effect component. The provinces differ by their size and productivity growth rates. In reporting the results by certain common characteristics one should use weighted averages. The weighted average rate of technical change, using provinces share of national GDP, is computed and the weighted mean values for different provinces, regions and years are reported on Table 7.

Insert Table 7 Mean values of TC and TFP components about here

The purely exogenous technical change varies greatly among the provinces. The highest mean rate is for Guangxi (4.7\%) and Cunan (4.4\%), while Shangahi $(-2.45)$ and seven other provinces show a negative rate of technical change. Looking at the regional level, the Central region shows the highest rate followed by West and East regions. Since the purely exogenous technical change is represented by a time trend, the mean rate is steadily declining over time from $+12.7 \%$ to $-4.8 \%$.

The technical change due to external economic factors is composed of two technology indices, index1 and index2. The first one is human capital and economic reform as infrastructures for purchase, attraction of and acquisition of technology, and technology transfer and learning capability of provinces. The second index is based on information technology and foreign direct investment. The parameter estimates show that the first index is weakly significant, but the second one is highly significant. Their interactive coefficient is negative suggesting a substitution relationship. However, their predicted values are positively, but marginal effects are negatively correlated (see Table 4).

These two indices are used to compute an aggregate measure of technological change based on external economic factors using the expression in (9). The mean predicted indices are positive for each province, region and year. Unlike the mean marginal effect for index1 which is positive in all dimensions, the mean marginal index2 is negative at all levels (see Table 7). It suggests that contribution from additional units of ICT and FDI to technical change is negative, but those of human capital and reform are positive.

\subsection{TFP growth and its decomposition}

The total factor productivity growth for the time trend production model (1) is computed using the formula in (8a). It is then decomposed into technical change and scale components. The technical change component is further decomposed into neutral and nonneutral components. The sample average TFP growth rate is $12.6 \%$. Contribution of technical change is positive (13.7), while scale component has a negative $(-1.15)$ 
contribution to the TFP growth. The TFP growth is computed at each point of the data. It ranged from $4.3 \%$ to $35.55 \%{ }^{4}$

The TFP growth based on the technology index model is computed using the formula (8b). It is then decomposed into its three main components, namely, the technical change component which is dominated by the time trend effect, the scale component and the technology index component. Each component is further decomposed into several subcomponents such as contributions from different technology shifters (indices).

The TFP growth obtained from the technology index model is much lower than the simple time trend production model. The weighted sample average TFP is $7.6 \%$. The contribution of scale, technical change and aggregate index components are $0.7 \%$ (6.6), 3.4\% (23.3) and $3.5 \%$ (77.3), respectively (see Table 6). The number in parenthesis is their shares (after removing a few extreme observations). Each component varies substantially. The dispersion in the technology index component is the largest with standard deviation of $12.7 \%$ and ranged from -41.9 to $+48.3 \%$. The correlation between TFP growth and its underlying components show that each component is positively correlated with TFP, but the technical change is negatively correlated with scale and technology index components (see Table 6). Note that the contribution from the scale component is negligible.

The difference in the economic size of the provinces and its heterogeneous changes over time implies TFP to be weighted. The weighted average TFP growth varied substantially across provinces. The highest growth rates are observed for Cobei, Guangdon, Fujian and Guangxi, while Qingcai, Ningxia, Beijing and Jiangxi show lowest growth rates. The source of growth differed across provinces, primarily due to the technology index component. The regional difference in TFP growth is small, but the Eastern region had the highest rate and Western region had the lowest. The development of TFP growth over time is quite pronounced. The growth rate reached its highest rate in 1994 (16.1\%), dropped to $0.9 \%$ in 2001, and then increased to $15.1 \%$ in 2003 (see Table 7). The main contributor to the large variations is technical change in the first part of the study period, while the technology index impacted most in the latter part. Again the scale effect is negligible.

\subsection{Provincial and regional heterogeneity}

The sustainable economic growth of China in recent decades combined with its enormous population, labor force, production and trade capacity and market size has turned the country into a major player in the global economy and a force not to be ignored. During the recent global recession China has emerged as one of few major economies registering continuous high growth rates. Despite its ongoing fragile structural reform program China is seen as a major force that can help to bring the world economy out of the current deep recession. China's active reform and state intervention-led growth model can be of use even to major transition and developing market economies. The gradual removal of different interventions has affected the flow of resources to increasingly productive areas and growing competition and leading role of state which has enabled the growth rate to

\footnotetext{
${ }^{4}$ In order to conserve space these are not reported here, but can be obtained from the authors upon request.
} 
accelerate. The gradualist approach and currency and capital account control seemed sensible and effectively sheltered China from the 1997 financial crisis and full effect of 2008 crisis. However, despite significant progress both India and China -- the two growing economic giants -- are criticized for being weak in the state's pro-poor actions to favor the poorest part of their populations in redistribution of achieved economic growth.

Table 8 provides information about development of key indicators of the Chinese economy during the reform period from 1970 till 2008. These include GDP, population, different industries share of output, patents, government expenditure, FDI, investment, trade, trade balance and exchange rate. The total GDP in current prices during 1970-2008 is increased by more than 133 times, while population is increased by 60 percent. The corresponding growth in employment is $125 \%$. The GDP per capita in current prices is increased by 82 times. The increased GDP is also a result of shifts from concentration in primary industry production to secondary and tertiary. The share of primary industry declined from $35.2 \%$ to 11.3 , while the share of tertiary industry increased from 24.3 to $40.9 \%$. The number of patents applications and registration also has increased dramatically indicating increased investment in R\&D and gained technology development and capability in processing production. The government expenditure in current prices is increased by 72 times.

Insert Table 8 Development of the Chinese economy, 1970-2008

China has been successful in attracting FDI. The inflow of FDI increased by more than 95 times during 1983 to 2008 and investment in fixed assets in current prices is increased by 190 times. The high investment rate and accumulation of capital stock has created a strong and capable production base. Exports have increased much more than import leading to large positive trade balance in particular from 1995. The exchange rate was fixed until 1980, but it depreciated continuously from 150RMB in 1971 to 828 in 2004 and then appreciated to 695RMB per 100 US\$ in 2008. The state controlled exchange rate has been a source of international competitiveness and rapidly expanded Chinas export. It also has been a source of criticism from Western countries concerning the trade balance and the prospect for a possible deterioration of global economic recovery.

Coming down from the aggregate level to the province and region level, one gets a very different picture. There are significance differences in all the indicators across regions and provinces. The Eastern region is the driving force behind the rapid economic development and high economic growth in China, while the Western region is the laggard. Regional income inequality and higher concentration of poverty are evidence of the increased gap. Massive investment in public infrastructure and inter-provincial equalizing investment plans has reduced the regional disparity but it has not been very successful in bridging the gap and enhancing growth and development among the regions to desirable levels.

\section{SUMMARY AND CONCLUSIONS}

This paper was concerned with specification and estimation of technical change by utilizing observable internal and external determinants of technological change. We estimate total factor productivity growth and its decomposition into technical change, scale 
economies and technology index components. Marginal effects of technology indicators on productivity growth are also estimated. In modeling technical change our focus is on various key factors associated with it. These technology shifters are investment in human capital and information and communication technology, flow of foreign direct investment and state initiated reform programs.

For the empirical analysis we used a balanced panel data on output and inputs and production and technology characteristics for Chinese provinces observed for the period 1993 to 2003. The analysis is expected to improve our understanding of the causes and patterns of provincial technical change and TFP growth in China. It enhances our knowledge on the recent years of unbalanced regional development in China. Information on differences in regional productivity growth is important for the central and regional governments to formulate coordinated policies of allocation and redistribution of productive resources to reduce the growing within and between regional inequalities.

We believe that this study contributed to the literature in a number of ways. First, it specified the technical change in terms of purely exogenous factor (time trend) and exogenous economic technology shifter factors. Second, we use panel data methodology and flexible functional form in which we control for effects not necessarily associated with technological change. Third, the model is applied to estimation of productivity growth in Chinese provinces during the country's rapid and continuous growth period. Fourth, unlike other previous growth studies of China which mainly used growth accounting approach, this study applies the panel data econometrics approach for estimation of the production function and thereby able to control for unobservable province effects.

The estimation results showed that the technology index model is the preferred specification in modeling production technology. The fit of the models is very good. The parameters of the two technology indices were of expected sign. Various input elasticities and growth measures are estimated. The return to scale is low, suggesting decreasing returns to scale. The capital and labor elasticities are negatively correlated, indicating that the two inputs are substitutes. The inputs elasticities and returns to scale measures have large dispersion across provinces and regions but are almost constant over time.

The time driven part of technical change varied significantly across the provinces and regions and its impacts on TFP steadily declined over time. The technology index based rate is composed of two technology indices. They represent infrastructure and carriers of technological change. The margin contribution from ICT and FDI is negative, but those of human capital and reform positive to rate of technological change. Their interactive coefficient is negative suggesting a substitution relationship.

The total factor productivity growth is decomposed into technical change (which is purely time driven), the scale and the technology index components. Each component is further decomposed into several sub-components such as contribution from different technology shifters. Each component varies greatly and the dispersion in the technology index component is the largest. The correlation between TFP growth and its underlying components show that each component is positively correlated with TFP, but the technical change is negatively correlated with scale and technology index components. The weighted 
average TFP growth varies across provinces. The sources of growth differ across provinces and are mainly attributed to differences in the technology index component. The regional difference in TFP growth is small, but the development of TFP growth over time is quite large. The main contributor to the large variation is technical change in the early years, while the technology index impacts the latter years. The scale effect is negligible. 


\section{REFERENCES}

Abramovitz, M. (1986). “Catching Up, Forging Ahead and Falling Behind.” Journal of Economic History 46, 385-406.

Arayama, Y. and K. Miyoshi. (2004). "Regional Diversity and Sources of Economic Growth in China.” The World Economy 27, 1583-1607.

Baltagi, B.H. and J.M. Griffin. (1988). "A Generalized Error Component Model with Heteroscedastic Disturbances.” International Economic Review 29, 745-753.

Bao, S., G.H. Chang, J.D. Sachs and W.T. Woo. (2002). “Geographic Factors and China's Regional Developments under Market Reforms, 1979-1998.” China Economic Review 13, 89-111.

Basu S.R. (2009), "Comparing China and India: Is the dividend of economic reforms polarized?”, European Journal of Comparative Economics 6(1), 57-99.

Becchetti, L., D.A. Londono Bedoya and L. Paganetto. (2003). "ICT Investment, Productivity and Efficiency: Evidence at Firm Level using a Stochastic Frontier Approach.” Journal of Productivity Analysis 20, 143-167.

Bensidoun I., F. Lemoine and D. Ünal (2009), "The integration of China and India into the world economy: a comparison”, European Journal of Comparative Economics 6(1), 131-151.

Blomstrom, M., R. Lipsey and M. Zejan. (1994). "What Explains the Growth of Developing Countries?” In Convergence and Productivity: Cross-National Studies and Historical Evidence, ed. William Baumol, Richard Nelson and Edward Wolff. Oxford: Oxford University Press.

Borensztein, E., J. De Gregeorio and J. Lee. (1998). "How does Foreign Direct Investment Affect Economic Growth?” Journal of International Economics 45, 115-135.

Borensztein, E. and D.J. Ostry. (1996). “Accounting for China’s Growth Performance.” American Economic Review 86, 224-228.

Chen B. and Y. Feng (2000), “Openness and trade policy in China: An industrial analysis”, China Economic Review 11 (2000) 323 \pm 341

Chen Z. and S. Song (2008), Efficiency and technology gap in China's agriculture: A regional meta-frontier analysis, China Economic Review 19, 287-296.

Chow, G. (1993). “Capital Formation and Economic Growth in China.” Quarterly Journal of Economics 108, 809-842.

Christensen, L.R., D.W. Jorgenson and L.J. Lau. (1973). "Transcendental Logarithmic Production Frontiers.” Review of Economics and Statistics 55, 28- 45.

Démurger, S. (2000). “Economic Opening and Growth in China.” OECD Development Centre Studies, Paris, March.

Démurger, S. (2001). “Infrastructure Development and Economic Growth: An Explanation for Regional Disparities in China?” Journal of Comparative Economics 29, 95-117.

Dewan, S. and K.L. Kraemer. (1998). "International Dimensions of the Productivity Paradox." Communications of the ACM 41, 56-62.

Dewan, S. and K.L. Kraemer. (2000). "Information Technology and Productivity: Evidence from Country-Level Data.” Management Science 46, 548-562.

Dougherty S. and V. Valli (2009), "Comparing China and India: an Introduction”, European Journal of Comparative Economics 6(1), 53-55. 
Ezaki, M. and L. Sun. (1999). "Growth Accounting in China for National, Regional, and Provincial Economies: 1981-1995.” Asian Economic Journal 13, 39-71.

Fleisher, B. and J. Chen. (1997). "The Coastal Non-Coastal Income Gap, Productivity, and Regional Economic Policy in China.” Journal of Comparative Economics 25, 220-236.

Gao T. (2004), "Regional industrial growth: evidence from Chinese industries”, Regional Science and Urban Economics 34, 101-124.

Gholami, R., S.Y. Lee and A. Heshmati. (2005). "The Causal Relationship between ICT and FDI.” Research Paper No. 2005/26, World Institute for World Economics Research.

Gipouloux, F. (1998). “Integration or Disintegration? The Spatial Effects of Foreign Direct Investment in China." China Perspectives 17, 6-13.

Gollop F., M. Frank and D.W. Jorgenson. (1980). "U.S. Productivity Growth by Industry, 1947-73.” In New Developments in Productivity Measurement and 60 Analysis, ed. John W. Kendrick and Beatrice N. Vaccara. Chicago: University of Chicago Press.

Gollop, F. and M. Roberts. (1983). "Environmental Regulations and Productivity Growth: The Case of Fossil-Fueled Electric Power Generation.” Journal of Political Economy 91, 654- 674.

Heshmati, A. and N. Nafar. (1998). "A Production Analysis of the Manufacturing Industries in Iran.” Technological Forecasting and Social Change 59, 183-196.

Hsieh C-T. and P.J. Klenow (2007), "Misallocation and manufacturing TFP in China and India” NBER Working Paper Series 2007:13290.

Hu, Z.L. and M.S. Khan. (1997). "Why is China Growing so Fast?” IMF Staff Papers. Washington, DC: International Monetary Fund.

Jorgenson, D.W. and B.M. Fraumeni. (1981). "Relative Prices and Technical Change.” In Modeling and Measuring Natural Resource Substitution, ed. E.R. Berndt and B.C. Fields. Cambridge, Mass: MIT Press: 17-47.

Karagiannis, G., P. Midmore and V. Tzouvelekas. (2002). "Separating Technical Change from Time-Varying Technical Inefficiency in the absence of Distributional Assumptions.” Journal of Productivity Analysis 18, 23-38.

Kash D.E., R.N. Auger and N. Li (2004), “An exceptional development pattern”, Technological Forecasting \& Social Change 71, 777-797.

Kraemer, K L. and J. Dedrick. (2001). "Information Technology and Productivity: Results and Policy Implications of Cross-Country Studies.” In Information Technology, Productivity, and Economic Growth, ed. M. Pohjola. Oxford: Oxford University Press.

Kumbhakar S. (2000), Estimation and Decomposition of Productivity Change when Production is not Efficient: A Panel Data Approach, Econometric Reviews, 19, 425460.

Kumbhakar, S.C., A. Heshmati and L. Hjalmarsson. (1999). "Parametric Approaches to Productivity Measurement: A Comparison among Alternative Models.” Scandinavian Journal of Economics 101, 405-424.

Lemoine F. and D. Unal-Kesenci (2004), “Assembly Trade and Technology Transfer: The Case of China”, World Development 32(5), 829-850.

Liu Z. (2002), "Foreign Direct Investment and Technology Spillover: Evidence from China”, Journal of Comparative Economics 30, 579-602. 
Lu D. (2000), "Industrial policy and resource allocation: implications on China's participation in globalization”, China Economic Review 11, 342-360.

Maddison, A., (1998). Chinese Economic Performance in the Long Run. Paris: OECD.

Maddison, A., Wu H.X. (2008), “Measuring China's Economic Performance”, World Economics, 9(2), 13-34.

Markusen, J. and A. Venables. (1999). "Foreign Direct Investment as a Catalyst for Industrial Development.” European Economic Review 43, 335-356.

Meng, Q. and M. Li. (2002). "New Economy and ICT Development in China." Information Economics and Policy 14, 275-295.

Mody, A. and F.Y. Wang. (1997). "Explaining Industrial Growth in Coastal China: Economic Reforms... and What Else?” World Bank Economic Review 11, 293-325.

$\mathrm{Mu}$ Q. and K. Lee (2005), "Knowledge diffusion, market segmentation and technological catch-up: The case of the telecommunication industry in China”, Research Policy 34, 759-783.

Ng, Y.C. and C.M. Leung. (2002). "Regional Economic Performance in China: A Panel Data Estimation.” BRC Papers on China No. CP200204. Hong Kong Baptist University.

OCED. (1998). Open Market Matter: the Benefits of Trade and Investment Liberalisation. Paris: OCED.

Patnaik I and A. Shah (2009), "The difficulties of the Chinese and Indian exchange rate regimes”, European Journal of Comparative Economics 6(1), 157-173.

Schreyer, P. (2000). “The Contribution of Information and Communication Technology to Output Growth: A Study of the G7 Countries.” STI Working Paper 2000/2. Paris: OECD.

Solow, R.M. (1957). “Technical Change and the Aggregate Production Function.” The Review of Economics and Statistics 39, 312-320.

Soto, M. (2000). “Capital Flows and Growth in Developing Countries: Recent Empirical Evidence.” OCED Development Centre Technical Paper No. 160. Paris: OCED.

Tinbergen, J. (1942). “Critical Remarks on Some Business Cycle Theories.” Econometrica $10,129-146$.

Valli V. and D. Saccone (2009), "Structural Change and Economic Development in China and India”, European Journal of Comparative Economics 6(1), 101-129.

Wang, Y. and Y. Yao. (2003). "Sources of China's Economic Growth 1952-1999: Incorporating Human Capital Accumulation.” China-Economic-Review 14, 32-52.

Woo, W. (1998). "Chinese Economic Growth: Sources and Prospects." In the Chinese Economy, ed. Michel Fouquin and Françoise Lemoine. London: Economica.

World Bank. (1996). The Chinese Economy: Fighting Inflation, Deepening Reforms, Washington D.C..

Wu, Y. (1999). "Productivity and Efficiency in China's Regional Economics in Economic Efficiency and Productivity Growth.” In the Asian-Pacific Region, ed. Tsu-Tan Fu et al., Edward Elgar.

Wu, Y. (2004). China's Economic Growth: A Miracle with Chinese Characteristics. London: Routledge Curzon.

$\mathrm{Xu}$, B. (2000). "Multinational Enterprises, Technology diffusion, and Host Country 
Productivity Growth.” Journal of Development Economics 62, 477-493.

Yang C.H. (2009), “Technological Sources and Regional Productivity Growth in China”, China Economic journal 2(1), 73-92.

Yeung, G. and V. Mok. (2002). "Government Policy and the Competitive Advantages of Foreign-Financed Firms in Guangdong Province of Southern China.” Asian Business and Management 1, 227-247. 
Table 1. Summary statistics of the variables (total number of observations: NT=30x11=330).

\begin{tabular}{|c|c|c|c|c|c|c|}
\hline Variable & Mean & Median & Std Dev & Minimum & Maximum & $\begin{array}{l}\text { Coeff. of } \\
\text { Variation }\end{array}$ \\
\hline \multicolumn{7}{|c|}{ Year and location variables } \\
\hline YEAR & 1998.00 & 1998.00 & 3.17 & 1993.00 & 2003.00 & 0.16 \\
\hline EAST & 0.37 & 0.00 & 0.48 & 0.00 & 1.00 & 131.63 \\
\hline WEST & 0.37 & 0.00 & 0.48 & 0.00 & 1.00 & 131.63 \\
\hline CENTRAL & 0.27 & 0.00 & 0.44 & 0.00 & 1.00 & 166.08 \\
\hline \multicolumn{7}{|c|}{ Output, input and trend } \\
\hline GDP & 2743.91 & 1967.51 & 2480.24 & 37.28 & 13625.87 & 90.39 \\
\hline LAB & 2091.01 & 1812.69 & 1529.42 & 112.00 & 6335.30 & 73.14 \\
\hline CAP & 80933.29 & 54020.49 & 81340.48 & 2690.36 & 536026.79 & 100.50 \\
\hline TRN & 6.00 & 6.00 & 3.17 & 1.00 & 11.00 & 52.79 \\
\hline \multicolumn{7}{|c|}{ Technology shifters used } \\
\hline ICT & 153825.70 & 111977.57 & 148379.77 & 1964.47 & 961897.12 & 96.46 \\
\hline FDI & 4871194.50 & 1536090.93 & 8077427.63 & 2808.99 & 43012460.57 & 165.82 \\
\hline PCNT & 0.09 & 0.06 & 0.08 & 0.02 & 0.57 & 90.33 \\
\hline REFORM & 0.49 & 0.45 & 0.19 & 0.11 & 0.91 & 39.47 \\
\hline \multicolumn{7}{|c|}{ Other technology shifters } \\
\hline ROA & 46237.95 & 43655.50 & 30312.83 & 3677.00 & 183341.00 & 65.56 \\
\hline GOV & 11764.90 & 8534.80 & 11168.32 & 283.25 & 84104.73 & 94.93 \\
\hline INV & 31094.90 & 21413.21 & 29557.02 & 926.90 & 190985.40 & 95.05 \\
\hline TEL & 3630381.30 & 2372959.00 & 3891388.67 & 22168.00 & 20595000.00 & 107.19 \\
\hline OPEN & 0.28 & 0.13 & 0.34 & 0.04 & 2.05 & 121.29 \\
\hline \multicolumn{7}{|c|}{ Other variables } \\
\hline TRA & 46335245.51 & 9015423.68 & 106352735.34 & 354156.86 & 912397287.07 & 229.53 \\
\hline DEF & 1.11 & 1.10 & 0.09 & 0.88 & 1.40 & 8.33 \\
\hline CPI & 200.69 & 192.80 & 62.94 & 107.60 & 378.00 & 31.36 \\
\hline POP & 4110.35 & 3695.25 & 2812.10 & 232.00 & 11830.40 & 68.42 \\
\hline HIGH & 32855.03 & 28328.00 & 23814.74 & 764.00 & 137048.00 & 72.48 \\
\hline
\end{tabular}

Glossary of variables:

GDP: gross domestic product, LAB: labor, CAP: capital, TRN: time trend, ICT: information and communication technology, FDI: foreign direct investment, PCNT: share of highly educated labor, REFORM: reform, ROA: roads, GOV: government expenditure, INV: investment, TEL: telephones, OPEN: openness, TRA: trade, DEF: GDP deflator, CPI: consumer price index, POP: population, HIGH: number of people with university degree. 
Table 2. Pearson correlation matrix (NT=330 observations).

\begin{tabular}{|l|r|r|r|r|r|r|l|l|l|l|}
\hline & YEAR & ICT & LAB & GDP & CAP & INV & FDI & PCNT & Open & Reform \\
\hline YEAR & \multicolumn{1}{|c|}{1.000} & & & & & & & & & \\
\hline & & & & & & & & & & \\
\hline ICT & 0.422 & 1.000 & & & & & & & & \\
\hline & $(0.000)$ & & & & & & & & & \\
\hline LAB & 0.021 & 0.407 & 1.000 & & & & & & & \\
\hline GDP & $(0.700)$ & $(0.000)$ & & & & & & & & \\
\hline & \multicolumn{1}{|c|}{$(0.000)$} & $(0.000)$ & $(0.000)$ & & & & & & & \\
\hline CAP & 0.294 & 0.686 & 0.232 & 0.714 & 1.000 & & & & & \\
\hline & $(0.000)$ & $(0.000)$ & $(0.000)$ & $(0.000)$ & & & & & & \\
\hline INV & 0.360 & 0.818 & 0.448 & 0.912 & 0.869 & 1.000 & & & & \\
\hline & $(0.000)$ & $(0.000)$ & $(0.000)$ & $(0.000)$ & $(0.000)$ & & & & & \\
\hline FDI & 0.054 & 0.672 & 0.246 & 0.673 & 0.658 & 0.775 & 1.000 & & & \\
\hline & $(0.329)$ & $(0.000)$ & $(0.000)$ & $(0.000)$ & $(0.000)$ & $(0.000)$ & & & & \\
\hline PCNT & 0.259 & 0.300 & -0.258 & 0.163 & 0.576 & 0.377 & 0.270 & 1.000 & & \\
\hline & $(0.000)$ & $(0.000)$ & $(0.000)$ & $(0.003)$ & $(0.000)$ & $(0.000)$ & $(0.000)$ & & & \\
\hline Open & 0.004 & 0.534 & -0.064 & 0.395 & 0.525 & 0.559 & 0.806 & 0.495 & 1.000 & \\
\hline & $(0.945)$ & $(0.000)$ & $(0.249)$ & $(0.000)$ & $(0.000)$ & $(0.000)$ & $(0.000)$ & $(0.000)$ & & \\
\hline Reform & -0.203 & 0.327 & 0.391 & 0.474 & 0.368 & 0.464 & 0.556 & 0.115 & 0.464 & 1.000 \\
\hline & $(0.000)$ & $(0.000)$ & $(0.000)$ & $(0.000)$ & $(0.000)$ & $(0.000)$ & $(0.000)$ & $(0.037)$ & $(0.000)$ & \\
\hline
\end{tabular}

Note: p-values in parenthesis

Glossary of variables:

YEAR: year of observation, ICT: information and communication technology, LAB: labor, GDP: gross domestic product, CAP: capital, INV: investment, FDI: foreign direct investment, PCNT: share of highly educated labor, OPEN: openness, REFORM: reform. 
Table 3. Translog time trend and technology index parameter estimates.

\begin{tabular}{|c|c|c|c|c|c|c|c|c|c|}
\hline \multicolumn{5}{|c|}{ Linear translog time trend model } & \multicolumn{5}{|c|}{ Non-linear translog technology index model } \\
\hline Parameter & Estimate & std err & t-value & Prob. & Parameter & Estimate & std err & t-value & Prob. \\
\hline- & - & - & - & - & PCNT & 0.9779 & 0.0091 & 107.980 & 0.001 \\
\hline- & - & - & - & - & ICT & 0.7198 & 0.1441 & 5.000 & 0.001 \\
\hline Intercept & -2.0698 & 5.6289 & -0.370 & 0.713 & Intercept & -7.8292 & 4.9977 & -1.570 & 0.118 \\
\hline Lab & 3.5844 & 1.0084 & 3.550 & 0.000 & Lab & 2.8759 & 0.8392 & 3.430 & 0.001 \\
\hline Cap & -0.8518 & 0.6144 & -1.390 & 0.167 & Cap & 0.3289 & 0.6255 & 0.530 & 0.600 \\
\hline $\operatorname{Trn}$ & 0.1615 & 0.0534 & 3.020 & 0.003 & Trn & 0.2129 & 0.0609 & 3.490 & 0.001 \\
\hline- & - & - & - & - & Index1 & -0.8482 & 0.4421 & -1.920 & 0.056 \\
\hline- & - & - & - & - & Index2 & 0.0446 & 0.1565 & 0.280 & 0.776 \\
\hline LabxLab & -0.0322 & 0.0564 & -0.570 & 0.569 & LabxLab & -0.0167 & 0.0472 & -0.350 & 0.723 \\
\hline СархСар & 0.1141 & 0.0338 & 3.380 & 0.001 & СapxСap & 0.1075 & 0.0351 & 3.060 & 0.002 \\
\hline TrxxTrn & -0.0061 & 0.0006 & -9.480 & 0.000 & TrnxTrn & -0.0080 & 0.0007 & -11.810 & 0.001 \\
\hline- & - & - & - & - & Ind1xInd1 & -0.0791 & 0.0367 & -2.150 & 0.032 \\
\hline- & - & - & - & - & Ind2xInd2 & 0.0220 & 0.0071 & 3.080 & 0.002 \\
\hline LabxCap & -0.2476 & 0.0558 & -4.440 & 0.001 & LaxxCap & -0.2599 & 0.0554 & -4.700 & 0.001 \\
\hline LabxTrn & 0.0200 & 0.0052 & 3.880 & 0.001 & LabxTrn & 0.0320 & 0.0050 & 6.450 & 0.001 \\
\hline- & - & - & - & - & LabxInd1 & -0.1334 & 0.0402 & -3.320 & 0.001 \\
\hline- & - & - & - & - & LabxInd2 & 0.0371 & 0.0182 & 2.030 & 0.043 \\
\hline CapxTrn & -0.0090 & 0.0062 & -1.450 & 0.148 & CapxTrn & -0.0270 & 0.0066 & -4.090 & 0.001 \\
\hline- & - & - & - & - & CapxInd1 & 0.1746 & 0.0505 & 3.460 & 0.001 \\
\hline- & - & - & - & - & CapxInd2 & -0.0628 & 0.0221 & -2.840 & 0.005 \\
\hline- & - & - & - & - & TrnxInd1 & 0.0012 & 0.0057 & 0.210 & 0.836 \\
\hline- & - & - & - & - & TrnxInd2 & 0.0114 & 0.0026 & 4.360 & 0.001 \\
\hline- & - & - & - & - & Ind1xInd2 & -0.0386 & 0.0225 & -1.720 & 0.087 \\
\hline c2 & -0.1145 & 0.1015 & -1.130 & 0.260 & c2 & 0.0763 & 0.1093 & 0.700 & 0.486 \\
\hline c3 & 0.2055 & 0.1740 & 1.180 & 0.239 & c3 & 0.7937 & 0.1826 & 4.350 & 0.001 \\
\hline c4 & 0.3271 & 0.1113 & 2.940 & 0.004 & c4 & 0.7129 & 0.1317 & 5.410 & 0.001 \\
\hline c5 & 0.3347 & 0.1127 & 2.970 & 0.003 & c5 & 0.3508 & 0.1049 & 3.340 & 0.001 \\
\hline c6 & 0.8465 & 0.1875 & 4.510 & 0.001 & c6 & 1.2871 & 0.1876 & 6.860 & 0.001 \\
\hline c7 & 0.4294 & 0.1493 & 2.880 & 0.004 & c7 & 0.9898 & 0.1680 & 5.890 & 0.001 \\
\hline c8 & -0.0162 & 0.1157 & -0.140 & 0.889 & c8 & 0.4903 & 0.1614 & 3.040 & 0.003 \\
\hline c9 & 0.7345 & 0.2211 & 3.320 & 0.001 & c9 & 1.2969 & 0.2137 & 6.070 & 0.001 \\
\hline c10 & 0.8355 & 0.1892 & 4.420 & 0.001 & c10 & 1.3037 & 0.2011 & 6.480 & 0.001 \\
\hline $\mathrm{c} 11$ & -1.0065 & 0.1490 & -6.750 & 0.001 & $\mathrm{c} 11$ & -0.2260 & 0.1830 & -1.230 & 0.218 \\
\hline c12 & -0.9572 & 0.2456 & -3.900 & 0.001 & c12 & -0.2912 & 0.2649 & -1.100 & 0.273 \\
\hline c13 & -0.6672 & 0.1079 & -6.180 & 0.001 & c13 & -0.0371 & 0.1539 & -0.240 & 0.810 \\
\hline c14 & -0.7168 & 0.1043 & -6.870 & 0.001 & c14 & 0.0106 & 0.1580 & 0.070 & 0.947 \\
\hline
\end{tabular}




\begin{tabular}{|l|r|l|r|r|l|r|r|r|r|}
\hline c15 & -0.4997 & 0.1029 & -4.860 & 0.001 & c15 & 0.0172 & 0.1434 & 0.120 & 0.905 \\
\hline c16 & -0.0847 & 0.1123 & -0.750 & 0.452 & c16 & 0.4903 & 0.1509 & 3.250 & 0.001 \\
\hline c17 & -0.6137 & 0.1738 & -3.530 & 0.001 & c17 & 0.1339 & 0.1905 & 0.700 & 0.483 \\
\hline c18 & -0.7570 & 0.1291 & -5.870 & 0.001 & c18 & -0.0718 & 0.1676 & -0.430 & 0.669 \\
\hline c19 & -0.0239 & 0.2319 & -0.100 & 0.918 & c19 & 0.6687 & 0.2245 & 2.980 & 0.003 \\
\hline c20 & -0.0229 & 0.1468 & -0.160 & 0.876 & c20 & 0.5283 & 0.1664 & 3.180 & 0.002 \\
\hline c21 & -0.5238 & 0.1807 & -2.900 & 0.004 & c21 & 0.1640 & 0.1943 & 0.840 & 0.399 \\
\hline c22 & -0.1526 & 0.2650 & -0.580 & 0.565 & c22 & 0.5547 & 0.2470 & 2.250 & 0.026 \\
\hline c23 & -1.8508 & 0.1429 & -12.950 & 0.001 & c23 & -0.8967 & 0.1873 & -4.790 & 0.001 \\
\hline c24 & -0.9974 & 0.1405 & -7.100 & 0.001 & c24 & -0.1475 & 0.1782 & -0.830 & 0.409 \\
\hline c25 & -1.6623 & 0.6464 & -2.570 & 0.011 & c25 & -0.6020 & 0.5860 & -1.030 & 0.305 \\
\hline c26 & -0.7854 & 0.1178 & -6.670 & 0.001 & c26 & -0.2650 & 0.1495 & -1.770 & 0.077 \\
\hline c27 & -1.1930 & 0.1076 & -11.080 & 0.001 & c27 & -0.4854 & 0.1592 & -3.050 & 0.003 \\
\hline c28 & -1.4326 & 0.3969 & -3.610 & 0.001 & c28 & -0.4870 & 0.3797 & -1.280 & 0.201 \\
\hline c29 & -1.4483 & 0.3169 & -4.570 & 0.001 & c29 & -0.6500 & 0.3114 & -2.090 & 0.038 \\
\hline c30 & -0.5521 & 0.1291 & -4.280 & 0.001 & c30 & 0.1083 & 0.1721 & 0.630 & 0.530 \\
\hline & & & & & & & & & \\
\hline Obs & 330 & & & & Obs & 330 & & & \\
\hline R2 adj & 0.9956 & & & & R2 adj & 0.9974 & & & \\
\hline RMSE & 0.0737 & & & & RMSE & 0.0573 & & & \\
\hline Iterations & 1 & & & & Iterations & 24 & & & \\
\hline
\end{tabular}

Glossary of variables:

Dependent variable: GDP: gross domestic product,

Inputs: LAB: labor and CAP: capital,

Technology indicators: TRN: time trend; Index1 (PCNT: share of highly educated labor, and REFORM:

reform), and Index2 (ICT: information and communication technology, FDI: foreign direct investment). 
Table 4. Pearson correlation matrix, unweighted TC index, marginal effects of indicators (330 obs)

\begin{tabular}{|l|r|r|r|l|r|l|l|l|l|l|l|}
\hline & Index1 & Index2 & $\begin{array}{l}\text { ME } \\
\text { index1 }\end{array}$ & $\begin{array}{l}\text { ME } \\
\text { index2 }\end{array}$ & $\begin{array}{l}\text { ME- } \\
\text { ICT }\end{array}$ & $\begin{array}{l}\text { ME- } \\
\text { FDI }\end{array}$ & $\begin{array}{l}\text { ME- } \\
\text { Pcnt }\end{array}$ & $\begin{array}{l}\text { ME Re } \\
\text { form }\end{array}$ & $\begin{array}{l}\text { Elas- } \\
\text { Lab }\end{array}$ & $\begin{array}{l}\text { Elas- } \\
\text { Cap }\end{array}$ & RTS \\
\hline Index1 & 1.000 & & & & & & & & & & \\
\hline & & & & & & & & & & & \\
\hline Index2 & 0.714 & 1.000 & & & & & & & & & \\
\hline & $(0.001)$ & & & & & & & & & & \\
\hline ME-index1 & -0.066 & 0.010 & 1.000 & & & & & & & & \\
\hline & $(0.230)$ & $(0.854)$ & & & & & & & & & \\
\hline MEiindex2 & -0.263 & -0.003 & -0.340 & 1.000 & & & & & & & \\
\hline & $(0.001)$ & $(0.961)$ & $(0.001)$ & & & & & & & & \\
\hline ME-ICT & 0.275 & 0.440 & -0.440 & 0.244 & 1.000 & & & & & & \\
\hline & $(0.001)$ & $(0.001)$ & $(0.001)$ & $(0.001)$ & & & & & & & \\
\hline ME-FDI & 0.275 & 0.440 & -0.440 & 0.244 & 1.000 & 1.000 & & & & & \\
\hline & $(0.001)$ & $(0.001)$ & $(0.001)$ & $(0.001)$ & $(0.001)$ & & & & & & \\
\hline ME-Pcnt & 0.225 & 0.139 & 0.876 & -0.388 & -0.457 & -0.457 & 1.000 & & & & \\
\hline & $(0.001)$ & $(0.011)$ & $(0.001)$ & $(0.001)$ & $(0.001)$ & $(0.001)$ & & & & & \\
\hline ME-Reform & -0.585 & -0.270 & -0.013 & 0.192 & 0.155 & 0.155 & -0.495 & 1.000 & & & \\
\hline & $(0.001)$ & $(0.001)$ & $(0.808)$ & $(0.001)$ & $(0.005)$ & $(0.005)$ & $(0.001)$ & & & & \\
\hline ElasLab & -0.518 & -0.447 & 0.048 & 0.433 & -0.477 & -0.477 & -0.017 & 0.120 & 1.000 & & \\
\hline & $(0.001)$ & $(0.001)$ & $(0.390)$ & $(0.001)$ & $(0.001)$ & $(0.001)$ & $(0.759)$ & $(0.029)$ & & & \\
\hline ElasCap & 0.744 & 0.617 & 0.376 & -0.527 & 0.004 & 0.004 & 0.583 & -0.530 & -0.279 & 1.000 & \\
\hline & $(0.001)$ & $(0.001)$ & $(0.001)$ & $(0.001)$ & $(0.939)$ & $(0.939)$ & $(0.001)$ & $(0.001)$ & $(0.001)$ & & \\
\hline RTS & 0.070 & 0.042 & 0.318 & 0.010 & -0.434 & -0.434 & 0.411 & -0.278 & 0.712 & 0.476 & 1.000 \\
\hline & $(0.202)$ & $(0.444)$ & $(0.001)$ & $(0.852)$ & $(0.001)$ & $(0.001)$ & $(0.001)$ & $(0.001)$ & $(0.001)$ & $(0.001)$ & \\
\hline
\end{tabular}

Note: p-values in parenthesis

Glossary of variables:

Index1 and Index2: technology indices: Index1 (Pcnt and Reform) and Index2 (ICT and FDI)

ME-index1 and ME-Index2: marginal effects with respect to technology Indix1 and Index2.

ME-ICT, ME-FDI, ME-Pcnt and ME-Reform: marginal effects with respect to technology indicators ICT, FDI, Pcnt and Reform.

ElasLab, ElasCap and RTS: elasticities of labor, capital and returns to scale. 
Table 5. Pearson correlation matrix, weighted TFP components (NT=330 observations)

\begin{tabular}{|l|r|r|r|r|l|l|l|l|l|}
\hline & Scale & TC & Index & TFP & $\begin{array}{l}\text { Share } \\
\text { Index1 }\end{array}$ & $\begin{array}{l}\text { Share } \\
\text { Index2 }\end{array}$ & $\begin{array}{l}\text { Share } \\
\text { Index }\end{array}$ & $\begin{array}{l}\text { Share } \\
\text { TC }\end{array}$ & $\begin{array}{l}\text { Share } \\
\text { Scale }\end{array}$ \\
\hline Scale component & 1.000 & & & & & & & & \\
\hline & & & & & & & & & \\
\hline TC component & -0.255 & 1.000 & & & & & & & \\
\hline & $(0.001)$ & & & & & & & & \\
\hline Index component & 0.032 & -0.275 & 1.000 & & & & & & \\
\hline & $(0.564)$ & $(0.001)$ & & & & & & & \\
\hline TFP & 0.002 & 0.172 & 0.896 & 1.000 & & & & & \\
\hline & $(0.970)$ & $(0.002)$ & $(0.001)$ & & & & & & \\
\hline Share Index1 & -0.360 & -0.117 & 0.176 & 0.092 & 1.000 & & & & \\
\hline & $(0.001)$ & $(0.033)$ & $(0.001)$ & $(0.096)$ & & & & & \\
\hline Share Index2 & 0.360 & 0.117 & -0.176 & -0.092 & -1.000 & 1.000 & & & \\
\hline & $(0.001)$ & $(0.033)$ & $(0.001)$ & $(0.096)$ & $(0.001)$ & & & & \\
\hline Share Index & 0.043 & -0.280 & -0.021 & -0.151 & 0.109 & -0.109 & 1.000 & & \\
\hline & $(0.439)$ & $(0.001)$ & $(0.705)$ & $(0.006)$ & $(0.050)$ & $(0.050)$ & & & \\
\hline Share TC & -0.106 & 0.310 & -0.025 & 0.113 & -0.115 & 0.115 & -0.933 & 1.000 & \\
\hline & $(0.056)$ & $(0.001)$ & $(0.655)$ & $(0.042)$ & $(0.038)$ & $(0.038)$ & $(0.001)$ & & \\
\hline Share Scale & 0.189 & -0.082 & 0.055 & 0.035 & -0.091 & 0.091 & -0.188 & 0.260 & 1.000 \\
\hline & $(0.001)$ & $(0.139)$ & $(0.317)$ & $(0.533)$ & $(0.102)$ & $(0.102)$ & $(0.001)$ & $(0.001)$ & \\
\hline
\end{tabular}

Note: p-values in parenthesis

Glossary of variables:

Scale: scale; TC: technical change; Index: technology index components; of TFP: total factor productivity. Share Index1; share of index1; Share Index2; share of index2; of the Index: overall technology index.

Share Index: share of technology index; Share TC: share of technical change; and Share Scale: scare component share of TFP. 
Table 6. Unweighted mean technology components by different characteristics (NT=330 obs)

\begin{tabular}{|c|c|c|c|c|c|c|c|c|c|c|c|}
\hline $\begin{array}{l}\text { A. } \\
\text { Province: }\end{array}$ & Index1 & Index2 & $\begin{array}{l}\text { ME- } \\
\text { index1 }\end{array}$ & $\begin{array}{l}\text { ME- } \\
\text { index2 }\end{array}$ & $\begin{array}{l}\text { ME- } \\
\text { ICT }\end{array}$ & $\begin{array}{l}\text { ME- } \\
\text { FDI }\end{array}$ & $\begin{array}{l}\text { ME- } \\
\text { Pcnt }\end{array}$ & $\begin{array}{l}\text { ME-Re } \\
\text { form }\end{array}$ & $\begin{array}{l}\text { Elas- } \\
\text { Lab }\end{array}$ & $\begin{array}{l}\text { Elas- } \\
\text { Cap }\end{array}$ & RTS \\
\hline Ancui & 0.062 & 0.071 & 0.492 & -0.265 & -0.054 & -0.021 & 0.390 & 0.102 & 0.298 & 0.033 & 0.332 \\
\hline Beijing & 0.403 & & 0.492 & -0.332 & -0.029 & -0.011 & 0.478 & 0.013 & -0.098 & 0.836 & 0.738 \\
\hline Cainan & 0.057 & 0.862 & 0.570 & -0.188 & -0.009 & -0.004 & 0.464 & 0.106 & 0.688 & 0.287 & 0.975 \\
\hline Cebei & 0.082 & & 0.599 & -0.302 & -0.039 & -0.015 & 0.495 & 0.104 & 0.018 & 0.246 & 0.264 \\
\hline Ceilongj & 0.100 & 0.114 & 0.541 & -0.306 & -0.079 & -0.031 & 0.494 & 0.047 & 0.208 & 0.329 & 0.537 \\
\hline Cenan & 0.062 & 0.059 & 0.561 & -0.300 & -0.060 & -0.024 & 0.436 & 0.124 & 0.101 & 0.078 & 0.179 \\
\hline Cubei & 0.106 & 0.170 & 0.495 & -0.289 & -0.040 & -0.016 & 0.436 & 0.059 & 0.134 & 0.245 & 0.379 \\
\hline Cunan & 0.077 & 0.100 & 0.430 & -0.254 & -0.043 & -0.017 & 0.361 & 0.069 & 0.290 & 0.027 & 0.317 \\
\hline Fujian & 0.091 & 0.892 & 0.448 & -0.203 & -0.008 & -0.003 & 0.360 & 0.087 & 0.332 & 0.153 & .484 \\
\hline Gansu & 0.067 & 0.053 & 0.623 & -0.319 & -0.150 & -0.058 & 0.549 & 0.073 & 0.315 & 0.328 & 0.644 \\
\hline Guangdon & 0.086 & 1.418 & 0.508 & -0.213 & -0.008 & -0.003 & 0.398 & 0.110 & 0.061 & 0.115 & 0.176 \\
\hline Guangxi & 0.055 & 0.111 & 0.452 & -0.223 & -0.028 & -0.011 & 0.355 & 0.097 & 0.462 & -0.040 & 0.422 \\
\hline Guizcou & 0.048 & 0.024 & 0.495 & -0.263 & -0.129 & -0.050 & 0.416 & 0.079 & 0.553 & -0.013 & 0.541 \\
\hline Jiangsu & 0.112 & 0.951 & 0.570 & -0.274 & -0.010 & -0.004 & 0.481 & .089 & -0.114 & 0.300 & 0.187 \\
\hline Jiangxi & 0.070 & & 0.508 & -0.258 & -0.034 & -0.013 & & .068 & .328 & 0.141 & 0.469 \\
\hline Jilin & 0.123 & & & & -0.060 & & & & & 0.408 & 0.645 \\
\hline Liaoning & 0.140 & 0.460 & 0.566 & -0.309 & -0.029 & -0.011 & .516 & & -0.025 & 0.451 & 0.426 \\
\hline Mongolia & 0.062 & 0.059 & 0.660 & -0.321 & -0.126 & -0.049 & 0.567 & 0.093 & 0.321 & 0.361 & 0.681 \\
\hline Ningxia & 0.061 & 0.057 & 0.641 & -0.302 & -0.163 & -0.063 & 0.573 & 0.068 & 0.667 & 0.469 & 1.137 \\
\hline Qingcai & 0.052 & 0.043 & 0.599 & -0.280 & -0.168 & -0.066 & 0.539 & 0.060 & 0.834 & 0.363 & 1.197 \\
\hline Scaanxi & 0.118 & 0.117 & 0.518 & -0.315 & -0.063 & -0.025 & 0.479 & 0.039 & 0.152 & 0.354 & 0.506 \\
\hline Shandong & 0.082 & 0.315 & 0.576 & -0.282 & -0.018 & -0.007 & 0.466 & 0.110 & -0.041 & 0.185 & 0.144 \\
\hline Shanghai & 0.287 & 3.329 & 0.651 & -0.339 & -0.014 & -0.005 & 0.621 & 0.031 & -0.242 & 0.890 & 0.649 \\
\hline Shanxi & 0.078 & & & -0.321 & -0.0 & -0.037 & & & & 0.340 & 0.575 \\
\hline & 0.061 & & & -0.284 & -0.067 & -0.026 & & & & -0.008 & 0.129 \\
\hline & 0.232 & & & & & & & & & & 0.869 \\
\hline Tibet & 0.040 & & & & & & & & & 0.288 & 1.390 \\
\hline Xinjiang & 0.077 & 0.043 & 0.641 & -0.338 & -0.207 & -0.081 & 0.584 & 0.057 & 0.373 & 0.457 & 0.830 \\
\hline Yunnan & 0.049 & 0.036 & 0.542 & -0.279 & -0.120 & -0.047 & 0.467 & 0.075 & 0.405 & 0.063 & 0.468 \\
\hline Zcejiang & 0.087 & 0.403 & 0.564 & -0.270 & -0.030 & -0.012 & 0.437 & 0.127 & 0.082 & 0.234 & 0.316 \\
\hline \multicolumn{12}{|l|}{ B. Region: } \\
\hline Central & 0.085 & & 0.518 & -0.287 & -0.058 & -0.023 & 0.445 & & 0.229 & 0.200 & 0.429 \\
\hline East & 0.151 & & 0.550 & -0.272 & -0.018 & -0.007 & 0.472 & 0.078 & 0.077 & 0.399 & 0.475 \\
\hline West & 0.063 & 0.062 & 0.569 & -0.285 & -0.120 & -0.047 & 0.492 & 0.077 & 0.484 & 0.238 & 0.722 \\
\hline \multicolumn{12}{|l|}{ C. Year: } \\
\hline 1993 & 0.073 & 0.420 & 0.549 & -0.314 & -0.029 & -0.011 & 0.450 & 0.100 & 0.222 & 0.322 & 0.543 \\
\hline 1994 & 0.076 & 0.436 & 0.541 & -0.307 & -0.059 & -0.023 & 0.441 & 0.100 & 0.248 & 0.300 & 0.548 \\
\hline
\end{tabular}




\begin{tabular}{|l|l|l|l|l|l|l|l|l|l|l|l|}
\hline 1995 & 0.092 & 0.448 & 0.510 & -0.299 & -0.056 & -0.022 & 0.429 & 0.081 & 0.256 & 0.298 & 0.553 \\
\hline 1996 & 0.095 & 0.488 & 0.511 & -0.291 & -0.059 & -0.023 & 0.423 & 0.088 & 0.269 & 0.286 & 0.555 \\
\hline 1997 & 0.096 & 0.532 & 0.521 & -0.279 & -0.057 & -0.022 & 0.427 & 0.094 & 0.281 & 0.268 & 0.549 \\
\hline 1998 & 0.094 & 0.523 & 0.548 & -0.275 & -0.066 & -0.026 & 0.454 & 0.094 & 0.285 & 0.270 & 0.555 \\
\hline 1999 & 0.091 & 0.435 & 0.581 & -0.270 & -0.080 & -0.031 & 0.516 & 0.065 & 0.290 & 0.262 & 0.552 \\
\hline 2000 & 0.094 & 0.365 & 0.588 & -0.269 & -0.087 & -0.034 & 0.523 & 0.065 & 0.288 & 0.268 & 0.556 \\
\hline 2001 & 0.102 & 0.492 & 0.584 & -0.258 & -0.087 & -0.034 & 0.520 & 0.064 & 0.291 & 0.263 & 0.554 \\
\hline 2002 & 0.126 & 0.496 & 0.568 & -0.260 & -0.071 & -0.028 & 0.516 & 0.051 & 0.268 & 0.288 & 0.556 \\
\hline 2003 & 0.170 & 0.499 & 0.534 & -0.268 & -0.078 & -0.030 & 0.497 & 0.037 & 0.234 & 0.332 & 0.566 \\
\hline D. Sample: & & & & & & & & & & & \\
\hline Mean & 0.101 & 0.467 & 0.549 & -0.281 & -0.006 & -0.026 & 0.472 & 0.076 & 0.267 & 0.289 & 0.553 \\
\hline Std Dev & 0.082 & 0.762 & 0.072 & 0.046 & 0.064 & 0.025 & 0.082 & 0.040 & 0.289 & 0.231 & 0.316 \\
\hline
\end{tabular}

Glossary of variables:

Technology indices: Index1 and Index2

Marginal Effects with respect to technology indices: ME-index1 and ME-Index2

Marginal effects with respect to technology indicators: ME-ICT, ME-FDI, ME-Pcnt and ME-Reform

Elasticities of Labor, Capital and returns to scale: ElasLab, ElasCap and RTS 
Table 7. GDP-based weighted mean technology components by different characteristics (330 obs)

\begin{tabular}{|c|c|c|c|c|c|c|c|c|c|}
\hline A. Province: & Scale & TC & Index & TFP & Sindex1 & Sindex2 & Sindex & STC & SScale \\
\hline Ancui & 0.004 & 0.037 & 0.054 & 0.095 & 0.471 & 0.529 & 0.816 & 0.168 & 0.016 \\
\hline Beijing & 0.015 & -0.012 & 0.032 & 0.035 & 0.208 & 0.792 & 0.406 & 0.739 & -0.145 \\
\hline Cainan & 0.001 & 0.016 & 0.062 & 0.078 & 0.077 & 0.923 & 0.816 & 0.183 & 0.000 \\
\hline Cebei & 0.019 & 0.015 & 0.095 & 0.129 & 0.355 & 0.645 & 0.991 & -0.016 & 0.025 \\
\hline Ceilongj & 0.007 & 0.013 & 0.069 & 0.089 & 0.482 & 0.518 & 0.873 & 0.185 & -0.058 \\
\hline Cenan & 0.006 & 0.029 & 0.072 & 0.107 & 0.521 & 0.479 & 1.167 & -0.188 & -0.192 \\
\hline Cubei & 0.016 & 0.024 & 0.042 & 0.082 & 0.384 & 0.616 & 1.301 & -0.112 & -0.284 \\
\hline Cunan & 0.002 & 0.044 & 0.037 & 0.083 & 0.435 & 0.565 & 0.161 & 0.825 & 0.014 \\
\hline Fujian & 0.014 & 0.035 & 0.062 & 0.111 & 0.106 & 0.894 & 0.501 & 1.151 & 0.463 \\
\hline Gansu & 0.009 & 0.002 & 0.059 & 0.070 & 0.565 & 0.435 & 1.908 & 0.020 & 0.520 \\
\hline Guangdon & 0.012 & 0.040 & 0.071 & 0.124 & 0.068 & 0.932 & 0.397 & 0.455 & 0.148 \\
\hline Guangxi & 0.001 & 0.047 & 0.063 & 0.111 & 0.364 & 0.636 & 0.594 & 0.316 & 0.015 \\
\hline Guizcou & 0.002 & 0.033 & 0.021 & 0.056 & 0.630 & 0.370 & 1.411 & -0.420 & 0.008 \\
\hline Jiangsu & 0.028 & 0.023 & 0.041 & 0.092 & 0.106 & 0.894 & 0.390 & 0.059 & 0.462 \\
\hline Jiangxi & 0.006 & 0.029 & -0.013 & 0.023 & 0.319 & 0.681 & 0.934 & 0.089 & -0.024 \\
\hline Jilin & 0.010 & 0.008 & 0.064 & 0.081 & 0.476 & 0.524 & 0.091 & 0.676 & 0.233 \\
\hline Liaoning & 0.018 & 0.011 & 0.026 & 0.054 & 0.243 & 0.757 & 0.847 & -0.288 & 0.441 \\
\hline Mongolia & 0.009 & -0.006 & 0.077 & 0.080 & 0.514 & 0.486 & 1.031 & 0.005 & -0.036 \\
\hline Ningxia & -0.005 & -0.016 & 0.039 & 0.018 & 0.530 & 0.470 & 0.749 & 0.228 & 0.023 \\
\hline Qingcai & -0.007 & -0.008 & 0.023 & 0.007 & 0.564 & 0.436 & 0.630 & 0.283 & 0.087 \\
\hline Scaanxi & 0.013 & 0.013 & 0.059 & 0.085 & 0.513 & 0.487 & 0.982 & -0.191 & 0.208 \\
\hline Shandong & 0.016 & 0.026 & 0.036 & 0.078 & 0.208 & 0.792 & 0.797 & 0.038 & 0.165 \\
\hline Shanghai & 0.029 & -0.024 & 0.035 & 0.039 & 0.083 & 0.917 & 1.363 & -0.561 & 0.197 \\
\hline Shanxi & 0.009 & 0.006 & 0.023 & 0.038 & 0.513 & 0.487 & 0.770 & 0.236 & -0.006 \\
\hline Sichccon & -0.002 & 0.035 & 0.055 & 0.089 & 0.544 & 0.456 & 1.672 & -0.801 & 0.129 \\
\hline Tianjin & 0.007 & -0.007 & 0.052 & 0.051 & 0.124 & 0.876 & 0.838 & 0.038 & 0.123 \\
\hline Tibet & -0.015 & -0.009 & 0.057 & 0.032 & 0.348 & 0.652 & 1.450 & -0.096 & -0.354 \\
\hline Xinjiang & 0.005 & -0.012 & 0.068 & 0.061 & 0.649 & 0.351 & 0.977 & -0.016 & 0.039 \\
\hline Yunnan & 0.004 & 0.028 & 0.032 & 0.064 & 0.579 & 0.421 & 0.971 & -0.018 & 0.047 \\
\hline Zcejiang & 0.020 & 0.021 & 0.044 & 0.085 & 0.181 & 0.819 & 0.560 & 0.235 & 0.206 \\
\hline \multicolumn{10}{|l|}{ B. Region: } \\
\hline central & 0.008 & 0.026 & 0.048 & 0.082 & 0.454 & 0.546 & 0.834 & 0.182 & -0.075 \\
\hline east & 0.019 & 0.019 & 0.050 & 0.088 & 0.160 & 0.840 & 0.669 & 0.164 & 0.230 \\
\hline west & 0.003 & 0.022 & 0.054 & 0.079 & 0.533 & 0.467 & 1.231 & -0.256 & 0.101 \\
\hline \multicolumn{10}{|l|}{ C. Year: } \\
\hline 1993 & 0.000 & 0.127 & 0.000 & 0.127 & 0.258 & 0.742 & 0.000 & 1.000 & 0.000 \\
\hline 1994 & 0.002 & 0.112 & 0.047 & 0.161 & 0.279 & 0.721 & 0.254 & 0.750 & -0.004 \\
\hline
\end{tabular}




\begin{tabular}{|l|r|r|r|r|r|r|r|r|r|}
\hline 1995 & 0.005 & 0.097 & 0.053 & 0.155 & 0.293 & 0.707 & 0.418 & 0.555 & 0.027 \\
\hline 1996 & 0.011 & 0.080 & 0.020 & 0.112 & 0.304 & 0.696 & 0.514 & 0.491 & -0.005 \\
\hline 1997 & 0.015 & 0.063 & -0.038 & 0.041 & 0.286 & 0.714 & 0.510 & 0.238 & 0.100 \\
\hline 1998 & 0.018 & 0.043 & -0.010 & 0.051 & 0.283 & 0.717 & 0.317 & 0.306 & 0.245 \\
\hline 1999 & 0.017 & 0.022 & -0.016 & 0.023 & 0.278 & 0.722 & 1.478 & -0.004 & -0.023 \\
\hline 2000 & 0.012 & 0.004 & 0.048 & 0.064 & 0.290 & 0.710 & 0.747 & 0.117 & 0.136 \\
\hline 2001 & 0.013 & -0.013 & -0.009 & -0.009 & 0.277 & 0.723 & 0.844 & 0.028 & 0.253 \\
\hline 2002 & 0.017 & -0.030 & 0.133 & 0.120 & 0.311 & 0.689 & 1.103 & -0.376 & 0.273 \\
\hline 2003 & 0.015 & -0.048 & 0.184 & 0.151 & 0.367 & 0.633 & 1.289 & -0.418 & 0.129 \\
\hline D. Sample: & & & & & & & & & \\
\hline Mean & 0.007 & 0.034 & 0.035 & 0.076 & 0.366 & 0.634 & 0.773 & 0.233 & 0.066 \\
\hline Std Dev & 0.011 & 0.059 & 0.127 & 0.124 & 0.200 & 0.200 & 1.243 & 1.133 & 0.519 \\
\hline
\end{tabular}

Glossary of variables:

Scale: scale; TC: technical change; Index: technology index components; of TFP: total factor productivity. Sindex1; share of index1; Sindex2; share of index2; of the Index: overall technology index.

Sindex: share of technology index; STC: share of technical change; and SScale: scale component share of TFP. 
Table 8. Development of the Chinese Economy, 1970-2008.

\begin{tabular}{|c|c|c|c|c|c|c|c|c|c|c|c|c|c|c|c|c|c|c|}
\hline Year & GDP & Populn & GDPcap & PriInd & SecInd & TerInd & PatApp & PatReg & GovExp & TTLExp & FDI & InvFA & Empl & TTLTr & Export & Import & TraBal & ExcRat \\
\hline 1970 & 2253 & 82992 & 275 & 35.2 & 40.5 & 24.3 & 0 & 0 & 29.9 & 4.61 & 0 & & 34432 & 113 & 57 & 56 & 0.7 & 246.0 \\
\hline 1975 & 2997 & 92420 & 327 & 32.4 & 45.7 & 21.9 & 0 & 0 & 40.3 & 4.91 & 0 & & 38168 & 290 & 143 & 147 & -4.4 & 150.0 \\
\hline 1976 & 2944 & 93717 & 316 & 32.8 & 45.4 & 21.8 & 0 & 0 & 39.2 & 4.87 & 0 & & 38834 & 264 & 135 & 129 & 5.5 & 150.0 \\
\hline 1977 & 3202 & 94974 & 339 & 29.4 & 47.1 & 23.5 & 0 & 0 & 41.5 & 4.92 & 0 & & 39377 & 272 & 140 & 133 & 6.9 & 150.0 \\
\hline 1978 & 3645 & 96259 & 381 & 28.2 & 47.9 & 23.9 & 0 & 0 & 52.9 & 4.71 & 0 & & 40152 & 355 & 168 & 187 & -19.8 & 150.0 \\
\hline 1979 & 4063 & 97542 & 419 & 31.3 & 47.1 & 21.6 & 0 & 0 & 62.3 & 4.86 & \multirow{4}{*}{17.7} & & 41024 & 455 & 212 & 243 & -31.2 & 149.0 \\
\hline 1980 & 4546 & 98705 & 463 & 30.2 & 48.2 & 21.6 & 0 & 0 & 64.6 & 5.26 & & 911 & 42361 & 570 & 271 & 299 & -27.6 & 150.0 \\
\hline 1981 & 4892 & 100072 & 492 & 31.9 & 46.1 & 22.0 & 0 & 0 & 61.6 & 5.41 & & 961 & 43725 & 735 & 368 & 368 & -0.1 & 170.5 \\
\hline 1982 & 5323 & 101654 & 528 & 33.4 & 44.8 & 21.8 & 0 & 0 & 65.3 & 5.31 & & 1230 & 45295 & 771 & 414 & 357 & 56.3 & 189.3 \\
\hline 1983 & 5963 & 103008 & 583 & 33.2 & 44.4 & 22.4 & 0 & 0 & 79.1 & 5.61 & 9.7 & 1430 & 46436 & 860 & 438 & 422 & 16.5 & $\begin{array}{l}197.6 \\
\end{array}$ \\
\hline 1984 & 7208 & 104357 & 695 & 32.1 & 43.1 & 24.8 & 0 & 0 & 94.7 & 5.57 & 14.7 & 1833 & 48197 & 1201 & 580 & 620 & -40.0 & 232.7 \\
\hline 1985 & 9016 & 105851 & 858 & 28.4 & 42.9 & 28.7 & N/A & N/A & 102.6 & 5.12 & 19.6 & 2543 & 49873 & 2067 & 809 & 1258 & -448.9 & 293.7 \\
\hline 1986 & 10275 & 107507 & 963 & 27.2 & 43.7 & 29.1 & N/A & N/A & 112.6 & 5.11 & 22.4 & 3121 & 51282 & 2580 & 1082 & 1498 & -416.2 & 345.3 \\
\hline 1987 & 12059 & 109300 & 1112 & 26.8 & 43.6 & 29.6 & 26077 & 6811 & $\begin{array}{l}113.8 \\
\end{array}$ & 5.03 & 23.1 & 3792 & 52783 & 3084 & 1470 & 1614 & -144.2 & 372.2 \\
\hline 1988 & 15043 & 111026 & 1366 & 25.7 & 43.8 & 30.5 & 34011 & 11947 & 121.1 & 4.86 & 31.9 & 4754 & 54334 & 3822 & 1767 & 2055 & -288.4 & 372.2 \\
\hline 1989 & 16992 & 112704 & 1519 & 25.1 & 42.8 & 32.1 & 32905 & 17129 & 127.9 & 4.53 & 33.9 & 4410 & 55329 & 4156 & 1956 & 2200 & -243.9 & 376.5 \\
\hline 1990 & 18668 & 114333 & 1644 & 27.1 & 41.3 & 31.6 & 41469 & 22588 & 139.1 & 4.51 & 34.9 & 4517 & 64749 & 5560 & 2986 & 2574 & 411.5 & 478.3 \\
\hline 1991 & 21782 & 115823 & 1893 & 24.5 & 41.8 & 33.7 & 50040 & 24616 & 160.7 & 4.74 & 43.7 & 5594 & 65491 & 7226 & 3827 & 3399 & 428.4 & 532.3 \\
\hline 1992 & 26924 & 117171 & 2311 & 21.8 & 43.4 & 34.8 & 67135 & 31475 & 189.3 & 5.06 & 110.1 & 8080 & 66152 & 9120 & 4676 & 4443 & 233.0 & 551.5 \\
\hline 1993 & 35334 & 118517 & 2998 & 19.7 & 46.6 & 33.7 & 77276 & 62127 & 225.6 & 4.86 & 275.2 & 13072 & 66808 & 11271 & 5285 & 5986 & -701.4 & 576.2 \\
\hline 1994 & 48198 & 119850 & 4044 & 19.8 & 46.6 & 33.6 & 77735 & 43297 & 268.2 & 4.63 & 337.7 & 17042 & 67455 & 20382 & 10422 & 9960 & 461.7 & 861.9 \\
\hline 1995 & 60794 & 121121 & 5046 & 19.9 & 47.2 & 32.9 & 83045 & 45064 & 302.4 & 4.43 & 375.2 & 20019 & 68065 & 23500 & 12452 & 11048 & 1403.7 & 835.1 \\
\hline 1996 & 71177 & 122389 & 5846 & 19.7 & 47.5 & 32.8 & 102735 & 43780 & 348.6 & 4.39 & $\begin{array}{l}417.3 \\
\end{array}$ & 22914 & 68950 & 24134 & 12576 & 11557 & 1019.0 & 831.4 \\
\hline 1997 & 78973 & 123626 & 6420 & 18.3 & 47.5 & 34.2 & 114208 & 50992 & 408.9 & 4.43 & 452.6 & 24941 & 69820 & 26967 & 15161 & 11807 & 3354.2 & 829.0 \\
\hline 1998 & 84402 & 124761 & 6796 & 17.6 & 46.2 & 36.2 & 121989 & 67889 & 438.6 & 4.06 & 454.6 & 28406 & 70637 & 26850 & 15224 & 11626 & 3597.5 & 827.9 \\
\hline 1999 & 89677 & 125786 & 7159 & 16.5 & 45.8 & 37.7 & 134239 & 100156 & 543.8 & 4.12 & 403.2 & 29855 & 71394 & 29896 & 16160 & 13737 & 2423.3 & 827.8 \\
\hline 2000 & 99215 & 126743 & 7858 & 15.1 & 45.9 & 39.0 & 170682 & 105345 & 575.6 & 3.62 & 407.1 & 32918 & 72085 & 39273 & 20634 & 18639 & 1995.6 & 827.8 \\
\hline 2001 & 109655 & 127627 & 8622 & 14.4 & 45.1 & 40.5 & 203573 & 114251 & 703.3 & 3.72 & 468.8 & 37213 & 73025 & 42184 & 22024 & 20159 & 1865.2 & 827.7 \\
\hline 2002 & 120333 & 128453 & 9398 & 13.7 & 44.8 & 41.5 & 252631 & 132399 & 816.2 & 3.70 & 527.4 & 43500 & 73740 & 51378 & 26948 & 24430 & 2517.6 & 827.7 \\
\hline 2003 & 135823 & 129227 & 10542 & 12.8 & 46.0 & 41.2 & 308487 & 182226 & 975.5 & 3.96 & 535.1 & 55567 & 74432 & 70484 & 36288 & 34196 & 2092.3 & 827.7 \\
\hline 2004 & 159878 & 129988 & 12336 & 13.4 & 46.2 & 40.4 & 353807 & 190238 & 1168.6 & 4.10 & 606.3 & 70477 & 75200 & 95539 & 49103 & 46436 & 2667.5 & 827.7 \\
\hline 2005 & 183217 & 130756 & 14053 & 12.2 & $\begin{array}{l}47.7 \\
\end{array}$ & 40.1 & 476264 & 214003 & 1334.9 & 3.90 & 603.3 & 88774 & 75825 & 116922 & 62648 & 54274 & 8374.4 & 819.2 \\
\hline 2006 & 211924 & 131448 & 16165 & 11.3 & 48.7 & 40.0 & 573178 & 267002 & 1688.5 & 4.20 & 630.2 & 109998 & 76400 & 140972 & 77595 & 63377 & 14218.0 & 797.2 \\
\hline 2007 & 249530 & 132129 & 18934 & 11.1 & 48.5 & 40.4 & 693917 & 351782 & 1783.0 & 3.60 & 747.7 & 137324 & 76990 & 166740 & 93456 & 73285 & 20171.0 & 760.4 \\
\hline 2008 & 300670 & 132802 & 22698 & 11.3 & 48.6 & 42.9 & 828328 & 411982 & 2129.2 & 3.40 & 923.9 & 172829 & 77480 & 179922 & 100395 & 79527 & 20868.4 & 694.5 \\
\hline
\end{tabular}

Glossary of variables:

GDP: gross domestic product; Populn: population; GDPcap: GDP per capita; PriInd, SecInd and TerInd: primary, secondary and tertiary industries share of GDP; PatApp and PatReg: patent applications and registrations; GovExp: government expenditure; TTL expenditure; FDI: foreign direct investment; InvFA: investment in fixed assets; Empl: employment; TTL tr: TTL trade; Export: export; Import: import; TraBal: trade balance; ExcRat: exchange rate. 